\title{
Nutritional Contribution Model of Litterfall for Adjacent Areas According to the Distance of Forest
}

\author{
Thomaz Costa ${ }^{1}$, Leon Costa $^{2}$ and Letícia Almeida ${ }^{2}$ \\ 1. Core of Water, Soil and Environmental Sustainability (NSAM), Embrapa Milho e Sorgo, Sete Lagoas, MG 35701-970, Brazil \\ 2. Agronomy Graduate Academy, São João Del Rei University (UFSJ), Sete Lagoas, MG 35702-031, Brazil
}

\begin{abstract}
The goal of this study is to evaluate the drift of litterfall from forest to adjacent areas, validate a method to estimate the drift with water balance, direction and speed of winds and quantify the nutrients of litterfall in nearby area of the forest patch as function of distance. This phenomenon can be considered an ecosystem service to improve soil quality of the agriculture crops around the forests by nutrient input coming from the litterfall. The experiment was installed in adjacent areas of the tropical forest at central region of the State of Minas Gerais, Brazil. The branches, reproductive material and leaves which fell were measured for three years into the forest and adjacents areas. The sampled nets were located on edge and equal distances from the edge. It's analyzed and estimated the contribution of the litterfall components to adjacent areas by air. The quantity of litterfall by distance had large variation between adjacent areas. And it was confirmed that model estimated the leaf drift by distance with good precision.
\end{abstract}

Key words: Wind analyze, modelling, ecosystem service.

\section{Introduction}

Litterfall is the organic layer deposited in forest ecosystems, with a singular role to act on the surface of the soil as an entrance and exit system, receiving first inputs through vegetation and fauna, and decomposing, supplying the roots with nutrients and organic matter. It is serving as a habitat for micro, meso and macro faunas that act in this process, and retaining and slowly releasing rainwater to the inner layers of the soil, besides contributing to the stabilization of erosion [1].

The nutrients absorbed by plants return to the soil by twigs, branches, flowers and fruits of plants and remains of animal and dead roots, and rainwater, which make up the ecosystem. This dynamic supports terrestrial ecosystems, releasing nutrients by biogeochemical and physical processes [2], and it is essential in establishing physical quality and biotic soil activity to restoration of soil fertility, especially in areas with ecological succession [3-5].

Corresponding author: Thomaz Costa, Ph.D., research field: forest science and remote sensing.
This layer deposited on the soil depends, in addition to the biomass production, on the decomposition rate of the organic matter, which varies according to the substrate composition, the activity of the decomposers and the environmental conditions, particularly temperature, humidity and soil physical properties [6]. It is known that the leaves form the largest amount in litterfall in forests, with approximately $70 \%$ of the deposited material [7-11].

The litterfall process, with rates of the deciduousness and decomposition of this material, as a key factor in the maintenance of nutrients in the ecosystem, should be more known, especially in the tropics, where there is great occurrence of soils with low levels of nutrients [12].

The amount of plant material deposited from forest ecosystems forming the litterfall is expressive, and reaches tons per hectare per year [7, 13-18]. The rate of litterfall is considered all the material deposited on the soil surface of a forest in a given period, which can be measured by deposition in collectors of pre-set sizes per unit time [19].

With information about the deposition, 
accumulation and decomposition of the litter, it is possible to define strategies for the sustainable management of a given ecosystem [20]. In the investigation of the interaction of forest with areas of their surroundings, the contribution of the forest can be relevant to improve the soil quality of these areas, often used for crops with low inputs in regions with hills, mountains and saws [21].

Costa, T. C. C. and Miranda, G. A. [21] verified the drift of a semideciduous seasonal forest patch, with the potential to restore $45 \%$ Ca exported from maize crops in low input crops, 20 meters away from the patch. They concluded that the release of nutrients to the surrounding areas via air deposition of the litter is environmental service that needs better evaluation in different configurations of the physical and biotic environment.

In the case of semideciduous forest, a typology conditioned by tropical climate seasonality, with a period of intense rains and another with severe drought, the litter deposition is mainly defined by the stock of water in the soil [10]. The lower temperature can be influence, too. This typology of the Atlantic Forest also occurs as enclaves in the Savannah. When associated with wavy and strongly wavy reliefs, it is usually left in environmental reserves on the property (Legal Reserve and Permanent Preservation Areas), with adjacency to small plots of cultivated land.

The functionality of forest ecosystems is increasingly present in environmental conservation policies and in payment for ecosystem services. They contribute to the regeneration of degraded areas in their surroundings through seed dispersal, and they offer habitats for pollinators and natural enemies of pests and of disease vectors [22, 23], cycle nutrients, store water, offer food [24], protect fauna and flora, bind carbon and contribute to buffering the local climate.

In 1997, a study calculated the value of environmental services of the planet between US\$ 16 and US\$ 34 trillion per year. The biological control accounted for US\$ 121 billion and pollination services accounted for US\$ 117 billion [25]. Moreover, if some research appears with reference to the crops and forests, most likely it will have focus of the impact of crop on forest. It is the case of Duncan, D. H., et al. [26], who analyzed the impact of fertilization of crops into nearby forest patches.

In this work, authors researched an unusual focus, the possibility of forest patches of the surrounding areas to help in the maintenance of soil fertility, with deposition of plant material and releasing of nutrients provided by derives from the litterfall. Therefore, this possible kind of ecosystem service was tested.

Thus, the present work aims to measure and estimate the contribution of litter to areas adjacent to patches of seasonal semideciduous forest and validate the methodology proposed by Costa, T. C. C. and Miranda, G. A. [21] to estimate the drift considering the effect of the water balance in the deciduousness, the direction and velocity of the winds.

\section{Material and Methods}

The study was conducted in three adjacent areas to tropical forest patches (51, 81 and 61 codes) at the experimental farm of Embrapa Milho e Sorgo in Sete Lagoas, State of Minas Gerais, Brazil and the characteristics of the patches to adjacent areas are shown in Fig. 1.

In area 51, for receiving litterfall, 19 nets, with mesh of $2 \times 2 \mathrm{~mm}$ and 3 meters of width with length between 10 and 35 meters, were installed on 13/07/11, from the edge of the patch, distanced 10 meters between nets (Figs. 1A and 1B). The evaluation was performed with 14 nets, because five nets were discarded for loss of quality or it was not possible to assess the origin of the contribution due to its location in relation to forest edges.

After 95 days, on 18/10/11, authors sampled litterfall deposition. They launched randomly a quadrant of $0.5 \times 0.5$ meters $\left(0.25 \mathrm{~m}^{2}\right)$ on edge and each 5 and 5 meters, from edge of patch (Fig. 1C). 
The litterfall was weighed and kept in incubator at $65{ }^{\circ} \mathrm{C}$ until stabilization to obtain the dry weight $\left(\mathrm{g} / \mathrm{m}^{2}\right)$. Authors had maintenance problem with this experiment. The conduction of the test was possible in the dry season after scraping soil, desiccation, mowing and weeding. During the rainy season, the growth of grasses and weeds lifted nets, precluding the maintenance and continuity of the evaluation.

In area 81, for receiving litterfall, collectors with 1 $\mathrm{m}^{2}$ of area and height of $1 \mathrm{~m}$ of the terrain were used, total of the 17 nets, 5 into the patch and 12 on adjacent area, subdivided in three lines spaced of 10 meters, of 4 nets $(0,5,10$ and 15 meters of the patch, Figs. 1D and $1 \mathrm{E})$.

The litterfall was collected on days 27/08/14, 26/09/14, 28/10/14, 26/11/14, 23/12/14, 29/01/15, 27/02/15 27/03/15, 29/04/15, 27/05/15, 28/06/15 and 28/07/15.

The collected material was separated on brunch, reproductive material and leaves, and the dry weight $\left(\mathrm{g} / \mathrm{m}^{2}\right)$ was obtained with the same routine of the 51 area.

In area 61, the same material was used (Fig. 1F). The difference is that the nets in adjacent area were distant 3, 8, 13 and 18 meters of the patch. The litterfall was collected on 28/08/2015, 30/09/2015, $30 / 10 / 2015,30 / 11 / 2015,29 / 12 / 2015,29 / 01 / 2016$, 26/02/2016, 28/03/2016, 28/04/2016, 30/05/2016, $30 / 06 / 2016$ and 29/07/2016.

Inside the patch in area 51, the monitoring of litter deposition was performed through 10 nets deployed in two plots of $20 \times 20 \mathrm{~m}$ on periods: 15/07/11, 15/08/11, $13 / 09 / 11,18 / 10 / 11,16 / 11 / 11,14 / 12 / 11,16 / 01 / 12$, 14/02/12, 15/03/12, 15/04/12, 14/05/12, 15/06/12 and $15 / 07 / 12$. The leaves of material that formed litter were monthly collected and weighed. The same routine was performed to patches 81 and 61 on its collect periods respectively, with following differences: five nets in one plot of $20 \times 20$ m were used for each patch and litterfall was separated in branches, reproductive material and leaves.
The collected leaves in each patch were split between dry and moist periods and ground and mixed for leaf analysis of macro (N, P, K, Ca and Mg) and micronutrients ( $\mathrm{Zn}, \mathrm{Fe}, \mathrm{Mn}$ and $\mathrm{Cu}$ ). It is used the content of dry and moist with dry weight of the correspondent periods.

The water balance of Thornthwaite was calculated with daily data of PET (Potential Evapotranspiration) by Penman-Monteith [27, 28], and the precipitation, with data obtained from the climatologic station of the INMET (National Institute of Meteorology), installed at the Embrapa Experimental Farm, distant around 6 $\mathrm{km}$ and $8 \mathrm{~km}$ of study areas. In order to calculate the daily water excess and the water deficiency, an available water capacity of $150 \mathrm{~mm}$ was used and the methodology described by Pereira, A. R., et al. [28] was carried out by the development of a VBA (Visual Basic for Application) routine [13]. The data were summed for the periods of leaves collecting in each area.

Into the patch, the period is considered for the estimation of the drift on adjacent area. It reflects the influence of the water balance on the deciduousness, caused by the climatic seasonality. This phenomenon can be associated with a second-degree polynomial model. With this model, using data of 2011/2012 [13], it recorded a minimum point between the end of February and the beginning of March. The September was the period with more fall of leaves.

The estimated litter drift by distance from the forest patch was obtained as: a reference period with observed data was chosen (August, September and October). This period was used by means of weighting factors between this and the other periods, which will be estimated. This weight is water balance influence on deciduousness.

For the influence of drifting wind, frequency tables by UTC (Universal Time Coordinated) time are used. The wind data obtained from the INMET weather station were organized into four frequency tables, 2 for speed $\left(\mathrm{m} \cdot \mathrm{s}^{-1}\right)$, and 2 for direction, for each UTC time, 


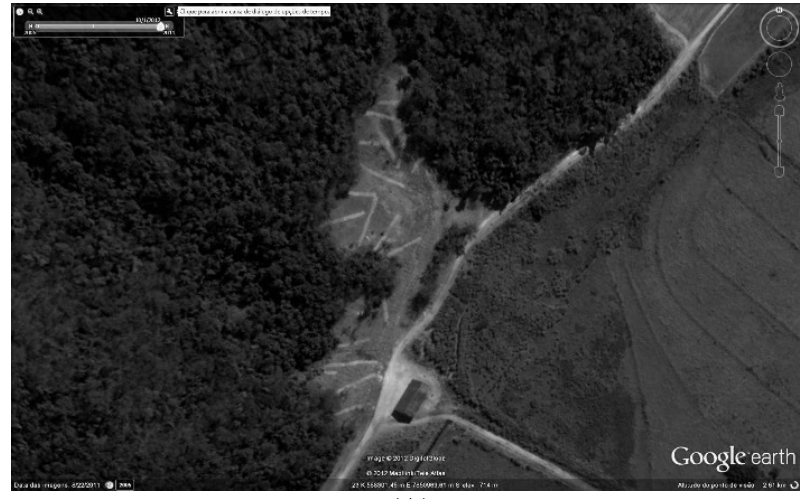

(A)

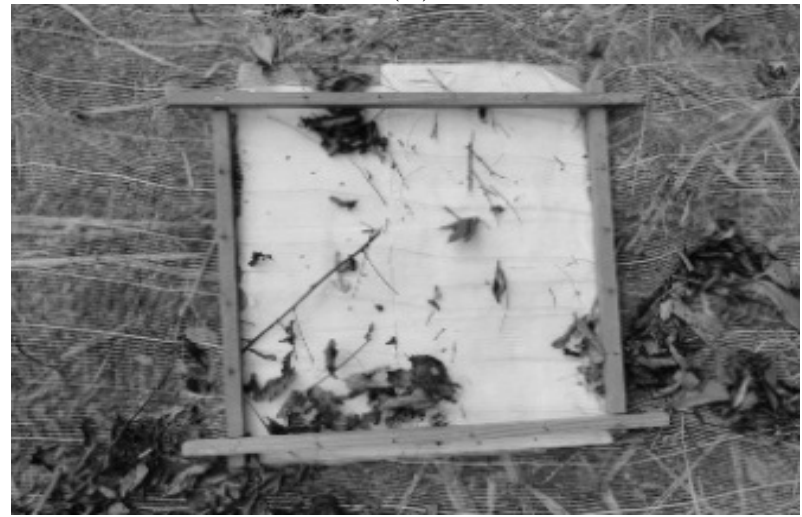

(C)

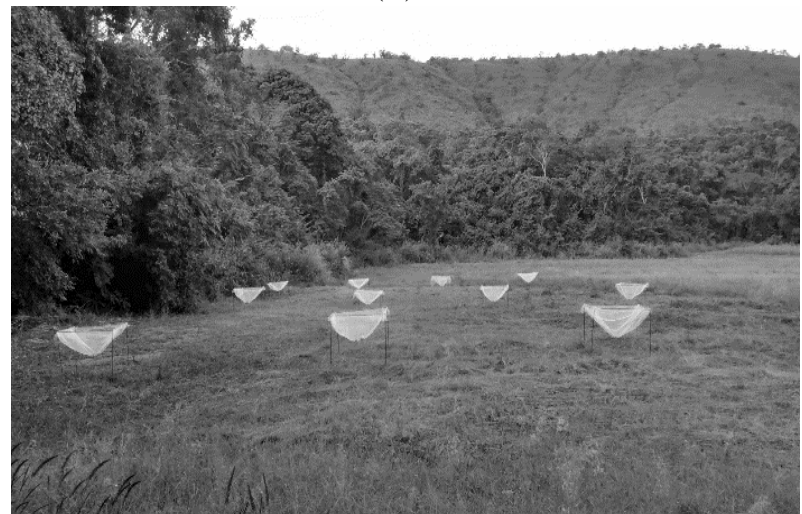

(E)

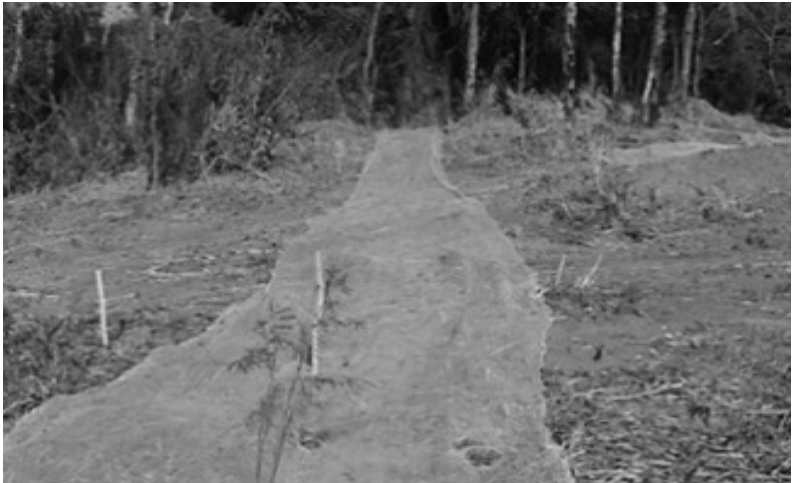

(B)

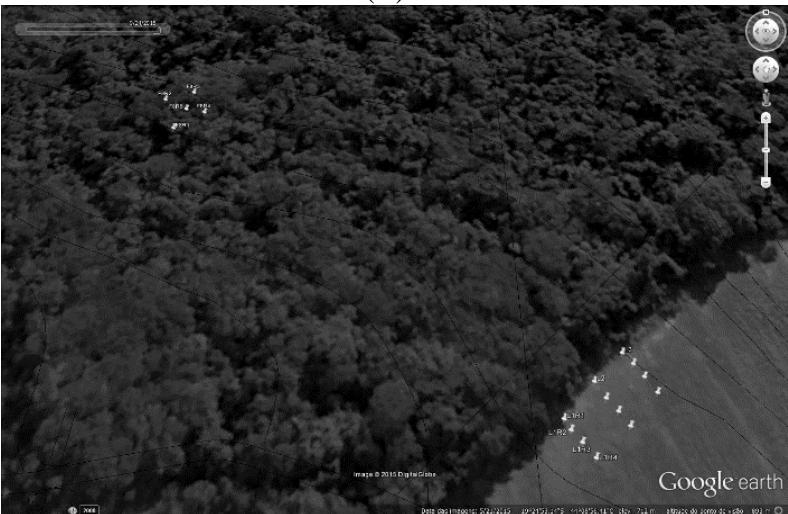

(D)

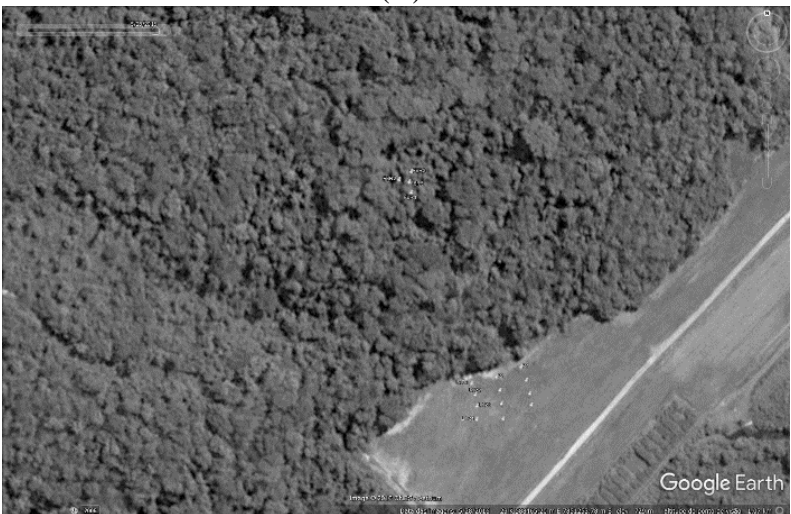

(F)

Fig. 1 Distribution of nets in the adjacent areas of forest at Embrapa Milho e Sorgo Farm and way of collection: (A) orbital view (Ikonos Image/Google Earth); (B) net detail; (C) quadrant of $0.5 \times 0.5 \mathrm{~m}$ randomly sampled in the edge, and distances of $5,10,15,20,25,30$ and 35 meters from the edge of the patch to litter collection in area 51; (D) layout of second experiment (area 81); (E) viewer of nets local; (F) layout of third experiment (area 61).

12, 18 hours. The time 24 hours was not used because the night collect was disabled during experiment. The unfavorable winds for litter drift in the surrounding area and days with lull were treated as no effective in the direction analysis. Because of the defect on anemometer, the lack of wind data occured in January and February 2012. This lack was filled with 2011 data.
For the wind speed tables (12 hours and 18 hours), a factor per period $\left(\mathrm{Fw}_{\mathrm{p}}\right)$ is generated. $\mathrm{Fw}_{\mathrm{p}}$ is weighted average that is calculated by the wind speed $\left(\mathrm{w}_{\mathrm{i}}\right)$ multiplied by its frequency of occurrence $\left(f_{i}\right)$, and divided by the total frequency $\left(\mathrm{f}_{\mathrm{t}}\right) \mathrm{n}$ is the number of wind speeds occurring in the period (Eqs. (1) and (2)).

$$
\mathrm{Fw}_{\mathrm{p}}=\sum_{i=1}^{n} \frac{\mathrm{w}_{\mathrm{i}} * \mathrm{f}_{\mathrm{i}}}{\mathrm{f}_{\mathrm{t}}}
$$




$$
\mathrm{f}_{\mathrm{t}}=\sum_{i=1}^{n} \mathrm{f}_{\mathrm{i}}
$$

This factor, compared between periods, indicates the greater or lesser influence of the wind speed in the drift.

In the direction tables, the winds that drift litter to the adjacent area were chosen by position. The factor per period in this case is the ratio between the sum of favorable wind frequencies ( $\mathrm{j}$ ) and the total frequency, including the lull (C) (Eqs. (3) and (4)).

$$
\begin{aligned}
\mathrm{Fw}_{\mathrm{p}} & =\sum_{j=1}^{n v} \frac{\mathrm{f}_{\mathrm{j}}}{\mathrm{f}_{\mathrm{t}}} \\
\mathrm{f}_{\mathrm{t}} & =\sum_{j=1}^{n} \mathrm{f}_{\mathrm{j}}
\end{aligned}
$$

To estimate the dry weight (whd) at the edge of the patch, the proportionality ratio between the period to be estimated and the reference period is used, with the water balance factor ( whd $_{\text {edge [ref.] }} /$ whd $_{\text {frag [ref.] }}$ ) and the wind factor $\left(\mathrm{Fw}_{\text {[period.] }} / \mathrm{Fw}_{[\text {[ref.] }}\right)$, expressed in Eq. (5).

$$
\frac{w h d_{\text {edge[period] }}}{w h d_{\text {frag[period }]}}=\frac{w h d_{\text {edge[ref] }}}{w h d_{\text {frag[ref }]}} * \frac{F w_{\text {[period }]}}{F w_{[\text {ref }]}}
$$

To estimate the dry weight (whd) of each litter component at the edge of the patch $(0 \mathrm{~m})$ in each period, this term is isolated in Eq. (6):

$$
\begin{gathered}
w h d_{\text {edge[period }]}\left(g \cdot m^{-2}\right)=w h d_{\text {frag[period }]} * \\
\frac{w h d_{\text {edge[ref }]}}{w h d_{\text {frag[ref }]}} * \frac{F w_{[\text {period] }}}{F w_{[\text {ref }]}}
\end{gathered}
$$

For the estimation of the whd at distances per period, the proportionality between the distance whd and the edge whd $(0 \mathrm{~m})$ in the reference period was used, with the distance whd to estimate and the whd of the edge of the period, estimated by Eq. (6).

All estimates, edge and distances are obtained by wind-frequency table, and the final whd $\left(\mathrm{g} \cdot \mathrm{m}^{-2}\right)$ value is obtained by the arithmetic mean per period among the 4 tables: speed wind to $12 \mathrm{~h}$ and $18 \mathrm{~h}$ and direction wind to $12 \mathrm{~h}$ and $18 \mathrm{~h}$.

Through leaf analysis of macro and micro nutrients of leaf litter collected in the inner forest patch, the amount of nutrients deposited on period and one year by distance was estimated. In case of area 51 , which did not separate the litterfall in branches, reproductive material and leafs, this estimate is possible because the nutrient content in the leaves compared to those found in the forming material litter did not vary much $[10,11]$.

The amounts of nutrients deposited in the soil were compared with data of exportation of nutrients for maize in productivity level with low input use.

\section{Results}

Table 1 shows the first characteristics about areas 51, 81 and 61. The areas 51 and 61 have the similar canopy (LAI, D, B) and hydric (DstWat, ElevWat) parameters, except for soil class and typology. In area 81, a river crosses with distance of 160 meters from the site, with altitude differences of 12 meters (Table 1), which gives the patch the classification of evergreen forest [29]. In areas 51 and 61, in which the patches are classified as semi deciduous seasonal forest, the river is 550 and 720 meters respectively away from the site [29].

Table 2 shows the correlations between climatic variables and leaf deposition. It is verified that the deciduousness increases with the reduction of the minimum temperature, the relative humidity and the rain, with the increase of the evapotranspiration, that reflects in the increase of the water deficit and reduction of the water surplus, conditions that characterize the dry season. In this region, it generally starts from March to April and ends from September to October. Wind influences the deciduous, especially in the hot times of the day, with greater turbulence of the atmosphere. These are the drive variables of leaf deposition in semi deciduous and deciduous forests, which can be summarized in the deficiency and surplus water, velocity and direction of the patch winds to adjacent areas.

The water balance shows that deciduousness declines with water surplus. In Fig. 2, the graphics on the right show variation of the leaves deposition within the patch by period. The lower rates of deciduousness are due to senescence of leaves and the influence of wind and small periods without rain in 
Table 1 Location, canopy and diversity parameters by site: LAI (Leaf Area Index); average tree height on edge canopy (h); density of individuals (D); basal area (B); Shannon index (H'); slope; distance of the water body (DstWat); elevation difference between the site and the water body (ElevWat); soil classes and forest typology of sites.

\begin{tabular}{|c|c|c|c|}
\hline Site & 51 & 81 & 61 \\
\hline Coordinates & $\begin{array}{l}44^{\circ} 09^{\prime} 33.45^{\prime \prime} \mathrm{O} \\
19^{\circ} 26^{\prime} 00.42^{\prime \prime} \mathrm{S}\end{array}$ & $\begin{array}{l}44^{\circ} 09^{\prime} 24.73 ” \mathrm{O} \\
19^{\circ} 25,53.91^{\prime \prime} \mathrm{S}\end{array}$ & $\begin{array}{l}44^{\circ} 08^{\prime} 54.91^{\prime \prime} \mathrm{O} \\
19^{\circ} 24^{\prime} 54.38^{\prime \prime} \mathrm{S}\end{array}$ \\
\hline $\begin{array}{l}\mathrm{LAI}\left(\mathrm{m}^{2} \text { of leaves and } \mathrm{m}^{-2} \text { of }\right. \\
\text { ground) }\end{array}$ & - & - & 4.2 \\
\hline $\mathrm{h}(\mathrm{m})$ & $19 \pm 3.48$ & $18 \pm 1.64$ & $9 \pm 1.59$ \\
\hline $\mathrm{D}\left(\right.$ ind $\cdot \mathrm{m}^{-2}$ ) & 0.09 & 0.18 & 0.09 \\
\hline $\mathrm{B}\left(\mathrm{m}^{2} \cdot \mathrm{ha}^{-1}\right)$ & 26 & 32 & 20 \\
\hline $\mathrm{H}^{\prime}$ & 2.64 & 2.87 & 2.47 \\
\hline Slope (degree) & $0-20^{\circ}$ & $0-7^{\circ}$ & $3-11^{\circ}$ \\
\hline DstWat (m) & 550 & 160 & 720 \\
\hline ElevWat (m) & 10 & 12 & 25 \\
\hline Soil class & Typical distrofic yellow argissol & $\begin{array}{l}\text { Typical hummic atrophic } \\
\text { cambissol }\end{array}$ & $\begin{array}{l}\text { Typical hummic distrofic } \\
\text { cambissol }\end{array}$ \\
\hline Tipology by usual method [29] & Semideciduous & Evergreen florest & Deciduous \\
\hline
\end{tabular}

Table 2 Pearson correlation matrix between climatic variables and leaf dry weight in the respective collection periods for areas 51, 81 and 61. Note 1: The averages were considered by period for the maximum, minimum and average temperatures in degrees Celsius (TMax, Tmin and Tmd), \% relative humid at $12 \mathrm{~h}$ and $18 \mathrm{~h}$ (UR12, UR18), wind velocity (m/s) at $12 \mathrm{~h}$ and $18 \mathrm{~h}(\mathrm{V12}, \mathrm{V18})$, and the cumulative, in $\mathrm{mm}$ in the period, for precipitation, potential evapotranspiration, water deficiency and surplus (PP, ET0, DEF and EXC). Dry leaf deposition is in $\mathrm{g} \cdot \mathrm{m}^{-2}$ (leaf). Values in bold are different from 0 with a significance level alpha $=0.05(n=36)$.

\begin{tabular}{|c|c|c|c|c|c|c|c|c|c|c|c|}
\hline Variables & TMax & TMin & Tmd & UR12 & UR18 & PP & ET0 & DEF & EXC & V12 & V18 \\
\hline TMin & 0.54 & & & & & & & & & & \\
\hline Tmd & 0.28 & 0.41 & & & & & & & & & \\
\hline UR12 & -0.56 & 0.27 & -0.16 & & & & & & & & \\
\hline UR18 & -0.33 & 0.56 & 0.01 & 0.92 & & & & & & & \\
\hline PP & 0.03 & 0.64 & 0.23 & 0.58 & 0.72 & & & & & & \\
\hline ET0 & 0.61 & -0.05 & 0.35 & -0.89 & -0.78 & -0.38 & & & & & \\
\hline DEF & -0.31 & 0.35 & -0.17 & 0.86 & 0.83 & 0.47 & -0.89 & & & & \\
\hline EXC & -0.07 & 0.47 & 0.12 & 0.57 & 0.65 & 0.95 & -0.40 & 0.43 & & & \\
\hline V12 & 0.35 & -0.13 & 0.25 & -0.75 & -0.60 & -0.38 & 0.73 & -0.73 & -0.42 & & \\
\hline V18 & 0.03 & -0.37 & 0.03 & -0.49 & -0.54 & -0.27 & 0.44 & -0.53 & -0.24 & 0.68 & \\
\hline Dry leaf & -0.23 & -0.74 & -0.15 & -0.48 & -0.62 & -0.48 & 0.39 & -0.57 & -0.37 & 0.38 & 0.52 \\
\hline
\end{tabular}

the summer season.

The data sums branches, reproductive material (flowers, fruits and seeds) and leaves, in $\mathrm{g} \cdot \mathrm{m}^{-2}$ by distance on areas 51, 81 and 61, are show in Figs. 3A, $3 \mathrm{~B}$ and $3 \mathrm{C}$, respectively. Fig. $3 \mathrm{~A}$ is two dimensions because in this area only one period of 95 days was collected. Fig. 3 shows litterfall deposited in greater quantity at edge of the patch. The leaves and flowers reach greater distances due to lower weights.

Comparing the areas (it is necessary to divide values of area 51 by 3, approximately because of period 3 months and three days), area 51 had major supply of litterfall followed by area 81 , and the area 61 had minor contribution.

In area 51, the collect method was different, the nets stayed on level of terrain and the area is more surrounded by vegetation (Fig. 1). In addition, the favorable conditions for litter drift refer to the higher slope of the terrain, with an inclined plane towards the collectors, reaching $20 \%$ of slope. These conditions can be contributing to more quantity of deposition litterfall. 

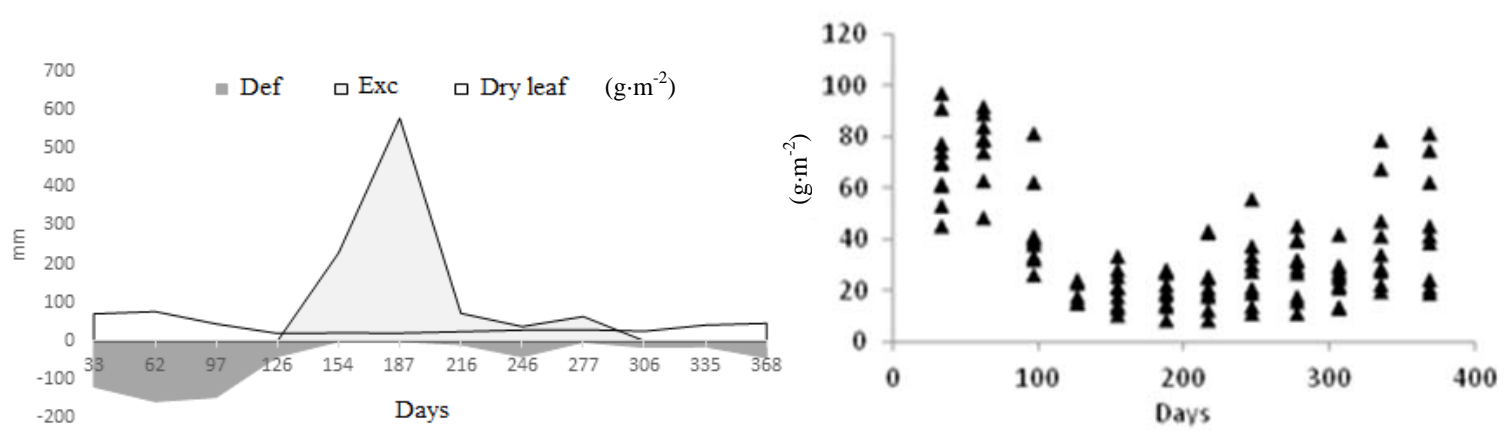

(A)
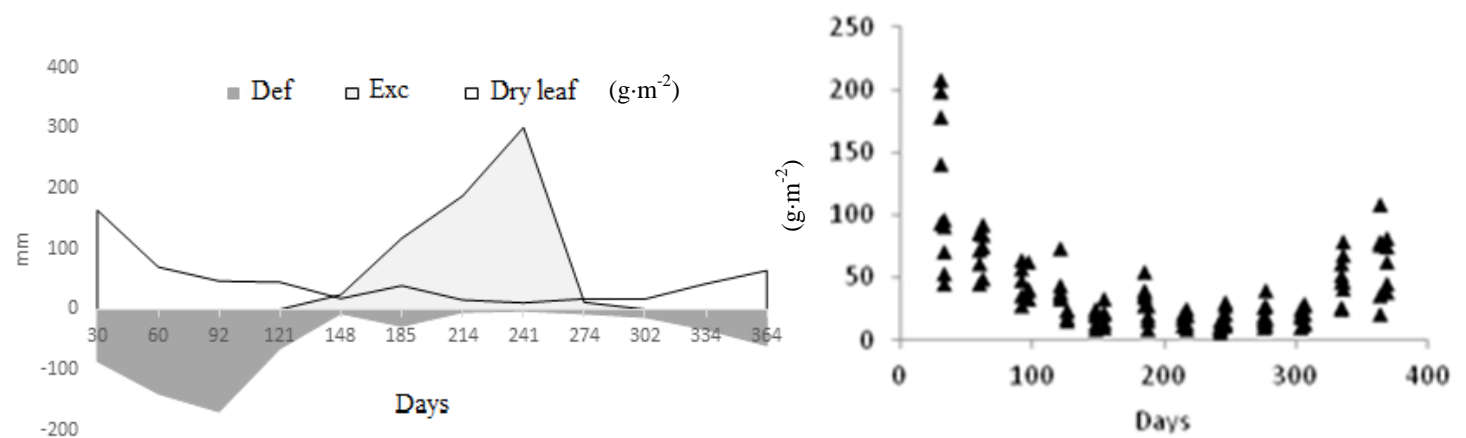

(B)
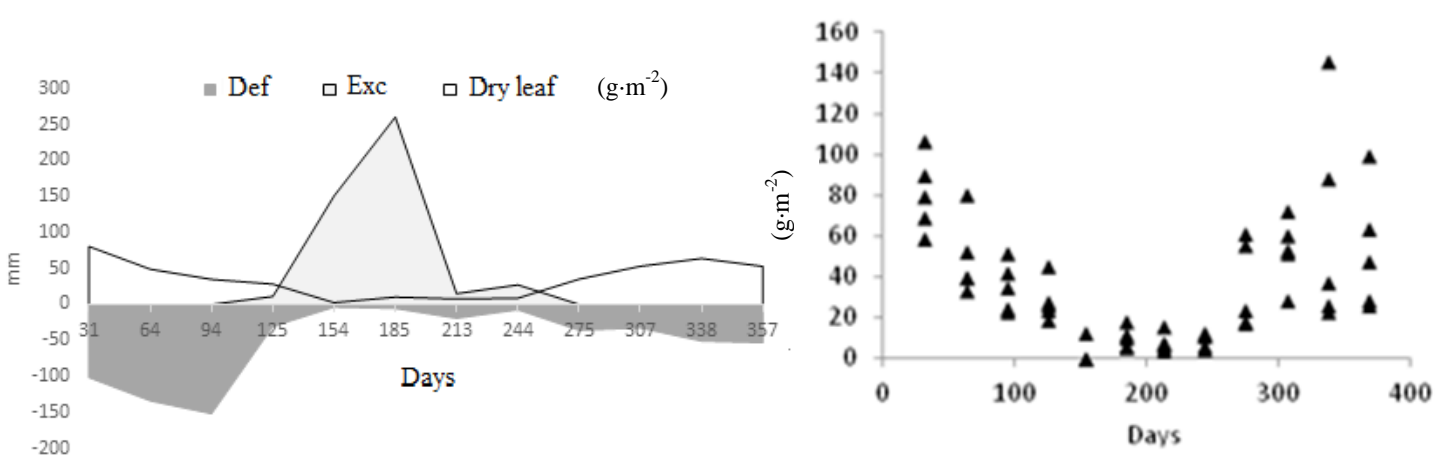

(C)

Fig. 2 Climatic water balance of Thornthwaite for 13/07/11-15/07/12 period (A), 28/07/14-28/07/15 (B) and 28/07/15-29/07/16 period $(C)$ and deciduousness, in average leaf dry weight $\left(\mathrm{g} \cdot \mathrm{m}^{-2}\right)$ gotten by nets installed in parcels of $20 \times 20 \mathrm{~m}$ inside the patch, distance of 80-100 meters from the edge, and observed values of leaf dry weight, to area 51, in period 15/08/11-15/07/12 (A), to area 81, in period 27/08/14-28/07/15 (B) and to area 61 in period 28/08/15-29/07/16 (C). Note 1: DEF (deficient) and EXC (surplus) water to each plant-available water capacity of the soil $=150 \mathrm{~mm}$, establishing the same accumulation period between the water balance and the leaf dry weight. Note 2: Potential evapotranspiration considered until 18/07/16, the last day of conventional climatic station operation. The radiation data of the automatic station was not calibrated when it began operation.

The area 81 has predominance of the vertical plane of the vegetation edge in front of collect nets due to lower slope. That is, the surface area to leave litterfall is minor compared to area 51.

Referred to area 61, distance of nets collectors begins in three meters and the height of trees is lower
(Table 1). Because of this, the litterfall is very lower in area 61.

The areas 81 and 61 are located on east, and the predominance of winds in the region is also from the east. Because of this, it reduces the amount of drift-contributing winds at direction of the patch to the 


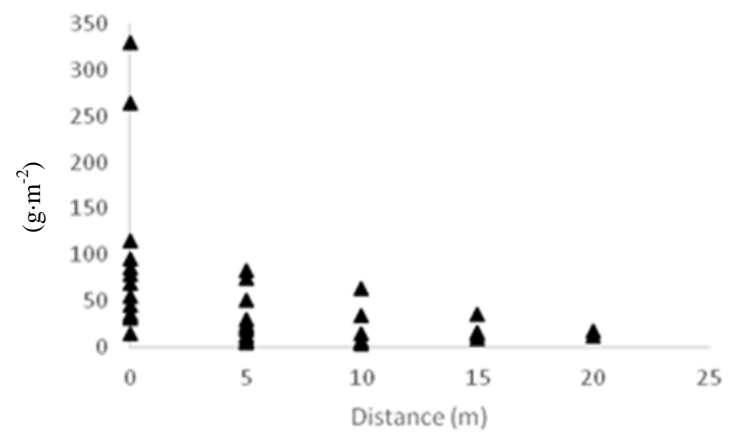

(A)

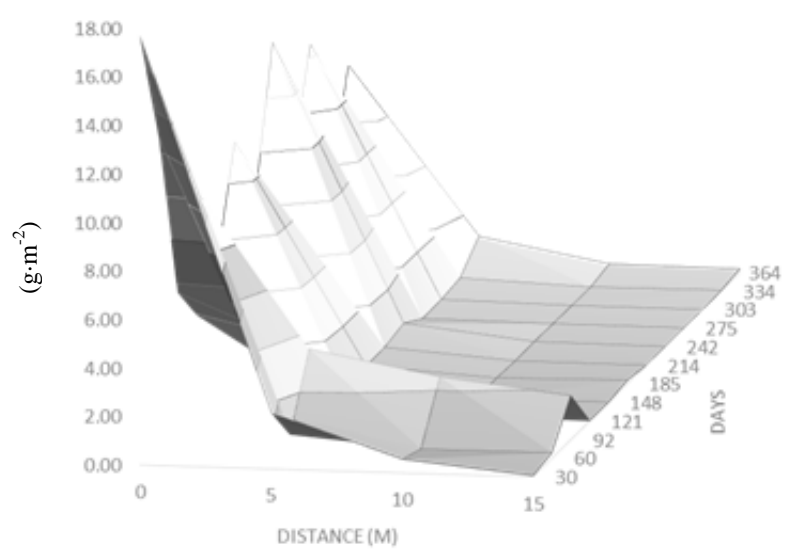

(B)

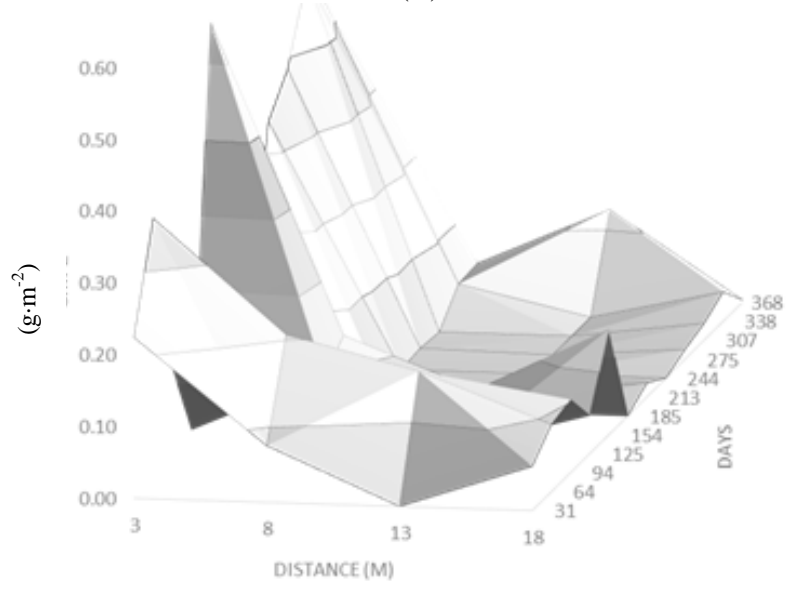

(C)

Fig. 3 Drift of litterfall (sum of branches, reproductive material and leafs) collected by distance in: (A) area 51 from period of 13/07/11 to 18/10/11 (95 days); (B) average values of the area 81; and (C) average values of the area 61 , by periods.

adjacent area.

Table 3 shows the velocity wind frequencies and Table 4 shows the direction wind frequencies, for three periods. The factors (Fwp) to velocity wind and direction wind in each period were calculated by Eqs.
(1)-(4).

In Fig. 4, authors can evaluate the estimates of model with wind and hydric balance. The area 51 has only one period with sums of components (br $+\mathrm{rm}+$ lf). The results shown in Fig. 4A correspond to the estimated values with and without the wind factor, without observed values.

In all areas and components of litterfall, estimates with model considering wind factor did not contribute enough to accuracy of results.

Authors supposed that it happened due to imprecision of wind. It is collected far 6-8 kilometers of areas and relief may interfere on direction and velocity.

In area 81, leaf deposition had the best estimate per period and yearly, followed by reproductive material. The estimate in area 61, three meters from edge distance per period, was the least accurate, including for leaf deposition, reflecting the annual distance estimate.

The amount of leaves deposited externally in the periods follows the same tendency into the patch, which does not occur for branches and reproductive material (flowers, fruits and seeds), because the water regime influences only the leaf drift.

In the comparison of the estimated and observed values, the branch component suffers less influence of winds due to its area/volume ratio. In addition, its fall has a predominant cause for the senescence in part of the plant, that is to say, the effect of the water deficit is not preponderant factor for fall of branches. The fall is also influenced by the increase of the weight by the absorption of the water by the wood, indicating that the rain can influence the fall of branches.

The reproductive material also showed large deviations between observed and estimated values, because the phenological phases of flowering and fruiting are not governed by winds and water regime only, and occur at different times among species. Thus, each site will produce propagules in different periods 
Table 3 Tables of frequency at hour 12 for speed wind and factor per period (Fwp). (Hours 18 were omitted because they are analogous to those presented).

\begin{tabular}{|c|c|c|c|c|c|c|c|c|c|c|c|c|c|}
\hline Sp. wind_12 h & 1 & 2 & 3 & 4 & 5 & 6 & 7 & 8 & 9 & 10 & 11 & 12 & Total \\
\hline 0 & 1 & & & & 5 & 9 & 4 & 2 & 4 & 4 & 4 & 3 & 36 \\
\hline 0.5 & 2 & 2 & 3 & 3 & 5 & 9 & 5 & 1 & 6 & 7 & 13 & 8 & 64 \\
\hline 1 & 7 & 2 & 2 & 5 & 9 & 6 & & 4 & 3 & 7 & 3 & 7 & 55 \\
\hline 1.2 & & & & & & 2 & 6 & 4 & & & & & 12 \\
\hline 1.5 & 10 & 10 & 9 & 9 & 2 & & & 3 & 8 & 9 & 7 & 9 & 76 \\
\hline 1.7 & & & & & & 2 & 3 & 1 & & & & & 6 \\
\hline 2.1 & 4 & 6 & 5 & 2 & 2 & 3 & & 1 & & 1 & 1 & 3 & 28 \\
\hline 2.4 & & & & & & & 3 & 3 & & & & & 6 \\
\hline 2.6 & 5 & 3 & 3 & 2 & 2 & & & & 1 & 1 & & 2 & 19 \\
\hline 2.9 & & & & & & & 3 & 4 & & & & & 7 \\
\hline 3.1 & 2 & & 1 & 2 & & 1 & & 2 & 2 & & 1 & 1 & 12 \\
\hline 3.6 & 1 & 1 & 4 & 3 & 2 & 1 & 4 & 4 & 4 & & & & 24 \\
\hline 4.1 & 1 & 3 & 2 & 3 & & & 1 & & 2 & & & & 12 \\
\hline 4.6 & & 1 & 3 & & & & & 1 & 1 & & & & 6 \\
\hline 5.1 & & 1 & 2 & & & & & & & & & & 3 \\
\hline 5.7 & & & 1 & & 1 & & & & & & & & 2 \\
\hline 1 Total & 33 & 29 & 35 & 29 & 28 & 33 & 29 & 30 & 31 & 29 & 29 & 33 & 368 \\
\hline Fwp & 1.77 & 2.21 & 2.59 & 2.02 & 1.31 & 0.89 & 1.70 & 2.05 & 1.74 & 0.99 & 0.87 & 1.18 & \\
\hline 0 & & 1 & & & & 1 & 1 & 2 & & & 1 & & 6 \\
\hline 0.5 & 4 & 2 & & & 4 & 2 & 4 & 1 & 3 & 5 & 9 & 5 & 39 \\
\hline 1 & 4 & 4 & 2 & 8 & 2 & 9 & 6 & 11 & 11 & 5 & 8 & 4 & 74 \\
\hline 1.5 & 5 & 2 & 5 & 7 & 4 & 14 & 7 & 6 & 7 & 4 & 6 & 14 & 81 \\
\hline 2.1 & 7 & 4 & 5 & 7 & 6 & 4 & 6 & 4 & 5 & 8 & 4 & 3 & 63 \\
\hline 2.6 & 4 & 4 & 4 & 1 & 5 & 3 & 3 & 2 & 2 & 1 & 2 & 1 & 32 \\
\hline 3.1 & 2 & 2 & 2 & 5 & 3 & 2 & & 1 & 4 & 1 & & 1 & 23 \\
\hline 3.6 & 1 & 1 & 5 & & 3 & 1 & & & 1 & 1 & 1 & 2 & 16 \\
\hline 4.1 & 2 & 4 & 3 & 1 & & & 1 & & & 3 & & & 14 \\
\hline 4.6 & & & 5 & & & & 1 & & & & 1 & & 7 \\
\hline 5.1 & 1 & & & & & & & & & & & & 1 \\
\hline 5.7 & & 2 & 1 & & & & & & & & & & 3 \\
\hline 6.2 & & 3 & & & & 1 & & & & & & & 4 \\
\hline 7.2 & & 1 & & & & & & & & & & & 1 \\
\hline 2 Total & 30 & 30 & 32 & 29 & 27 & 37 & 29 & 27 & 33 & 28 & 32 & 30 & 364 \\
\hline Fwp & 2.06 & 3.01 & 2.99 & 1.91 & 2.06 & 1.71 & 1.64 & 1.38 & 1.66 & 1.85 & 1.35 & 1.56 & \\
\hline 0 & & & 1 & & & 2 & & 4 & & 2 & & & 9 \\
\hline 0.5 & & 3 & & 1 & 3 & 3 & 5 & 5 & 2 & 7 & 2 & 2 & 33 \\
\hline 1 & 5 & 10 & 3 & 9 & 8 & 5 & 5 & 6 & 8 & 6 & 9 & 7 & 81 \\
\hline 1.5 & 9 & 10 & 5 & 9 & 7 & 13 & 11 & 7 & 10 & 7 & 9 & 4 & 101 \\
\hline 2.1 & 3 & 3 & 9 & 3 & 6 & 5 & 4 & 2 & 4 & 3 & 6 & 4 & 52 \\
\hline 2.6 & 3 & 2 & 5 & 4 & 2 & & 2 & 1 & 2 & 5 & 3 & 6 & 35 \\
\hline 3.1 & 2 & 2 & 3 & 3 & 2 & 2 & 1 & 3 & 1 & & 1 & 1 & 21 \\
\hline 3.6 & 3 & 1 & 2 & 1 & 1 & 1 & & 3 & 2 & 1 & 1 & 3 & 19 \\
\hline 4.1 & 1 & 1 & 2 & & & & & & 2 & 1 & & & 7 \\
\hline 4.6 & 1 & & & & & & & & & & & 2 & 3 \\
\hline 5.1 & 2 & & & & & & & & & & & 1 & 3 \\
\hline 5.7 & 1 & & & 1 & & & & & & & & & 2 \\
\hline 6.2 & & 1 & & & & & & & & & & & 1 \\
\hline 7.2 & 1 & & & & & & & & & & & & 1 \\
\hline 3 Total & 31 & 33 & 30 & 31 & 29 & 31 & 28 & 31 & 31 & 32 & 31 & 30 & 368 \\
\hline Fwp & 2.63 & 1.76 & 2.24 & 1.88 & 1.64 & 1.49 & 1.45 & 1.48 & 1.81 & 1.47 & 1.63 & 2.21 & \\
\hline
\end{tabular}


Table 4 Tables of frequency at hour 12 for direction wind and factor per period (Fwp).

\begin{tabular}{|c|c|c|c|c|c|c|c|c|c|c|c|c|c|}
\hline Dir. wind_12 h & 1 & 2 & 3 & 4 & 5 & 6 & 7 & 8 & 9 & 10 & 11 & 12 & Total \\
\hline no wind & 1 & & & & 5 & 6 & 2 & 3 & 4 & 4 & 4 & 4 & 33 \\
\hline $\mathrm{E}$ & 13 & 19 & 23 & 11 & 12 & 6 & 19 & 23 & 15 & 5 & 5 & 10 & 161 \\
\hline $\mathrm{N}$ & 1 & 4 & 2 & 2 & 6 & 11 & 1 & 1 & 1 & 1 & 3 & 1 & 34 \\
\hline $\mathrm{NE}$ & 2 & 1 & 4 & 6 & 1 & 5 & 1 & & 2 & 1 & 1 & & 24 \\
\hline NW & 1 & & & 1 & 2 & 3 & 1 & & & & & & 8 \\
\hline S & 1 & & 1 & 4 & & & & 1 & 4 & 10 & 6 & 6 & 33 \\
\hline SE & 11 & 5 & 3 & 5 & 2 & 2 & 5 & 2 & 3 & 5 & 7 & 7 & 57 \\
\hline SW & & & 1 & & & & & & 1 & 2 & 3 & 2 & 9 \\
\hline $\mathrm{W}$ & 3 & & 1 & & & & & & 1 & 1 & & 3 & 9 \\
\hline 1 Total & 33 & 29 & 35 & 29 & 28 & 33 & 29 & 30 & 31 & 29 & 29 & 33 & 368 \\
\hline Fwp & 0.21 & 0.17 & 0.23 & 0.31 & 0.32 & 0.58 & 0.10 & 0.03 & 0.16 & 0.17 & 0.24 & 0.18 & \\
\hline no wind & & 1 & & & & 1 & 1 & 2 & & & 1 & & 6 \\
\hline $\mathrm{E}$ & 16 & 18 & 20 & 13 & 9 & 19 & 15 & 12 & 16 & 9 & 12 & 15 & 174 \\
\hline $\mathrm{N}$ & & 1 & 1 & 1 & 4 & 3 & 3 & 4 & 1 & 2 & 1 & & 21 \\
\hline $\mathrm{NE}$ & 1 & 1 & 4 & 7 & 5 & 5 & 2 & 2 & & 2 & & 1 & 30 \\
\hline NW & 1 & & 1 & & & & 1 & & & 1 & & & 4 \\
\hline$S$ & 3 & 2 & 1 & 4 & 2 & 4 & & 2 & 6 & 10 & 6 & 4 & 44 \\
\hline SE & 6 & 7 & 5 & 3 & 6 & 3 & 4 & 2 & 7 & 4 & 6 & 8 & 61 \\
\hline SW & 1 & & & & & 2 & & & 2 & & 1 & 1 & 7 \\
\hline $\mathrm{W}$ & 2 & & & 1 & 1 & & 3 & 3 & 1 & & 5 & 1 & 17 \\
\hline 2 Total & 30 & 30 & 32 & 29 & 27 & 37 & 29 & 27 & 33 & 28 & 32 & 30 & 364 \\
\hline Fwp & 0.13 & 0.07 & 0.19 & 0.31 & 0.37 & 0.22 & 0.31 & 0.33 & 0.06 & 0.18 & 0.19 & 0.07 & \\
\hline no wind & & & 1 & & & 2 & & 4 & & 2 & & & 9 \\
\hline $\mathrm{E}$ & 21 & 13 & 12 & 9 & 10 & 9 & 10 & 8 & 15 & 7 & 5 & 11 & 130 \\
\hline $\mathrm{N}$ & & 3 & 1 & 6 & 4 & 7 & 3 & 5 & 1 & 2 & 1 & 1 & 34 \\
\hline $\mathrm{NE}$ & 1 & 2 & 8 & 7 & 3 & 4 & 5 & 1 & & 2 & & 1 & 34 \\
\hline NW & & & & & 1 & & & & 1 & & 1 & 1 & 4 \\
\hline S & 2 & 5 & 5 & & 6 & 3 & 1 & 1 & 2 & 8 & 4 & 5 & 42 \\
\hline SE & 7 & 8 & 3 & 8 & 3 & 4 & 8 & 11 & 11 & 8 & 10 & 10 & 91 \\
\hline SW & & & & 1 & 1 & & & 1 & & 1 & 5 & 1 & 10 \\
\hline $\mathrm{W}$ & & 2 & & & 1 & 2 & 1 & & 1 & 2 & 5 & & 14 \\
\hline 3 Total & 31 & 33 & 30 & 31 & 29 & 31 & 28 & 31 & 31 & 32 & 31 & 30 & 368 \\
\hline Fwp & 0.03 & 0.21 & 0.30 & 0.42 & 0.31 & 0.42 & 0.32 & 0.19 & 0.10 & 0.19 & 0.23 & 0.10 & \\
\hline
\end{tabular}

Note: shadow directions contribute to collectors.

according to the floristic diversity, confirming that samples inside the patch are not representative to infer in the drift of the reproductive material.

Table 5 shows the litterfall quantities deposited in the reference periods within the patch (only leafs), at the border and by distance of the patch (sum of branches, reproductive material and leaves). Although the periods are different, there is no relevant variation regarding the water regime and the favorable directions and speed frequencies of the winds strongly affecting the deciduousness.
In order to obtain a model with equation of the behavior of litterfall deposition in one year, authors worked with annual average values by distance. Fig. 5 shows the curve adjusted in the logarithmic model (Eq. (7)) for litter deposition $\left(\mathrm{g} \cdot \mathrm{m}^{-2}\right)$ versus the distance for the each period. The Eq. (8) of the area 51 with $\mathrm{R}^{2}$ 98.4\%, and Eqs. (9) and (10) with $\mathrm{R}^{2} 100 \%$ to area 81 and 61 respectively, were different.

The content and reach depend of conditions, how structure of vegetation, position of the fragment and adjacent area and wind. 


$$
\begin{gathered}
Y=a * \exp (b * X)+c \\
\text { d.w. }\left(g \cdot \mathrm{m}^{-2}\right)=190.64778193248 * \exp (-0.154435144400618 * \text { meters })+0
\end{gathered}
$$

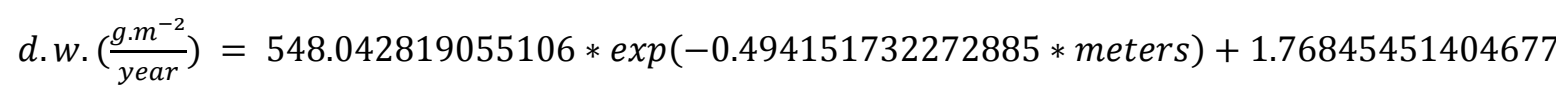

$$
\text { d.w. }\left(\frac{g \cdot m^{-2}}{\text { year }}\right)=426.670674190849 * \exp (-0.628153630058945 * \text { meters })+0.30328368906145
$$
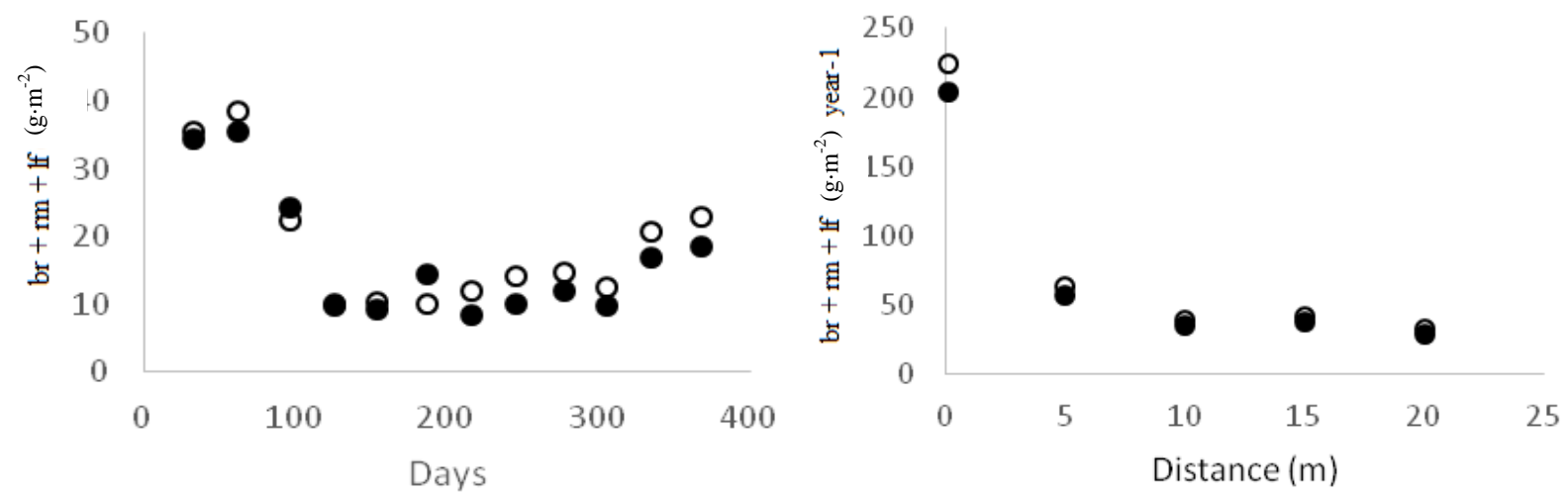

(A)
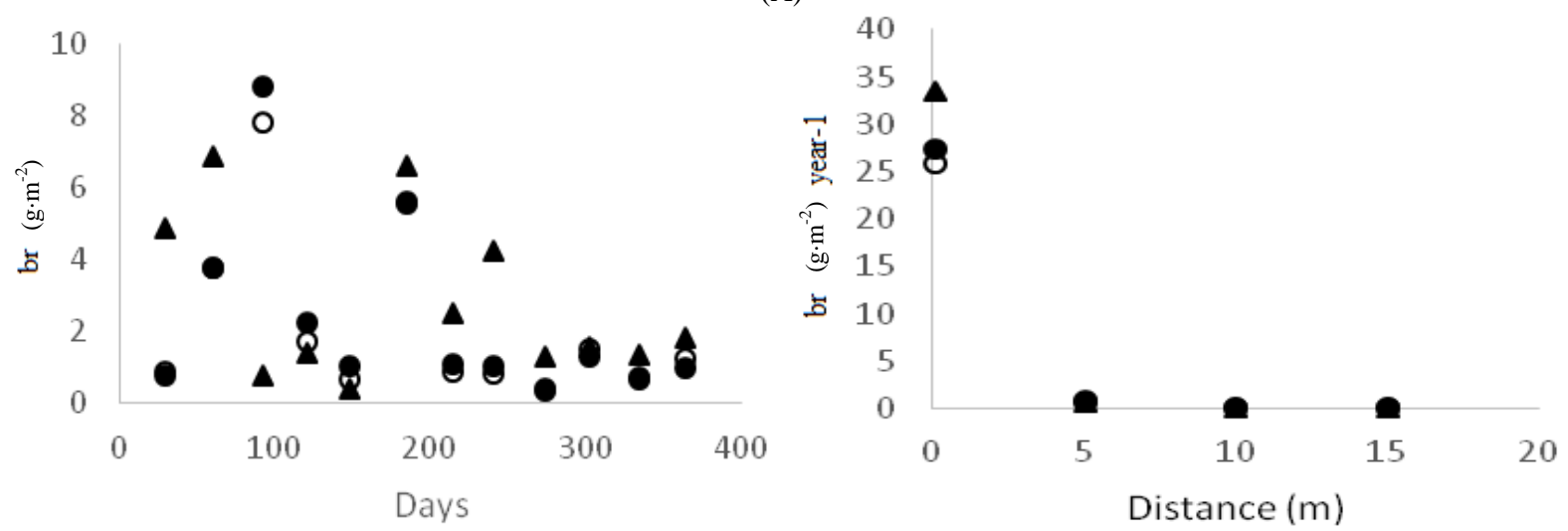

(B1)
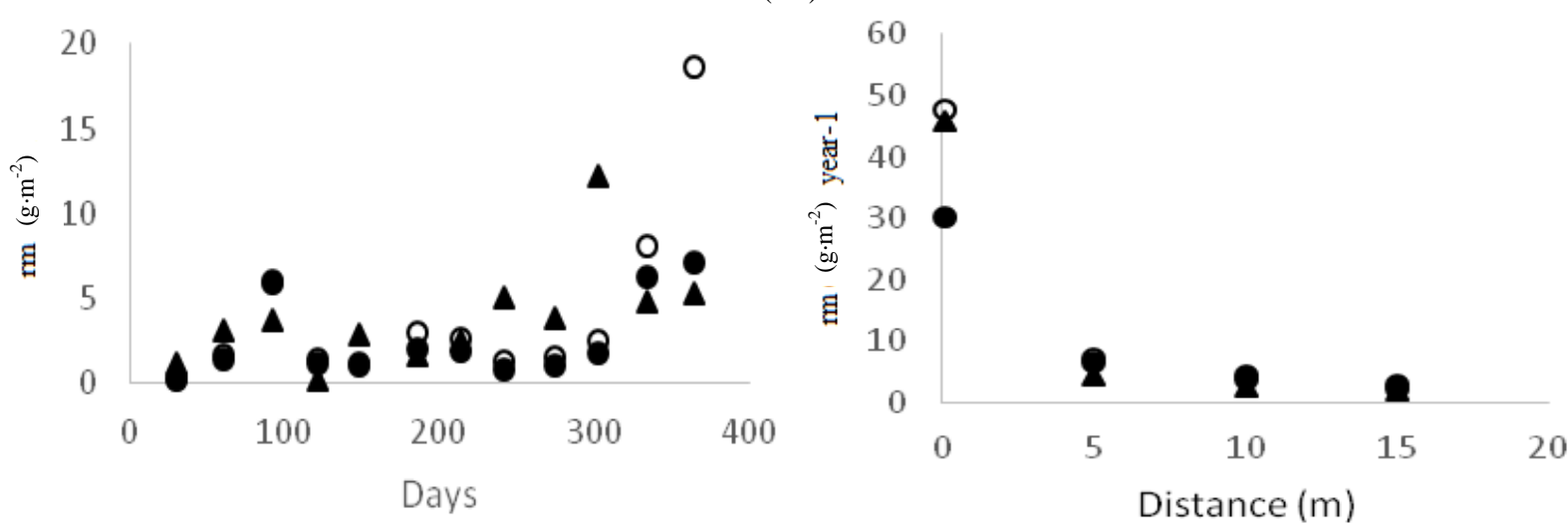

(B2) 

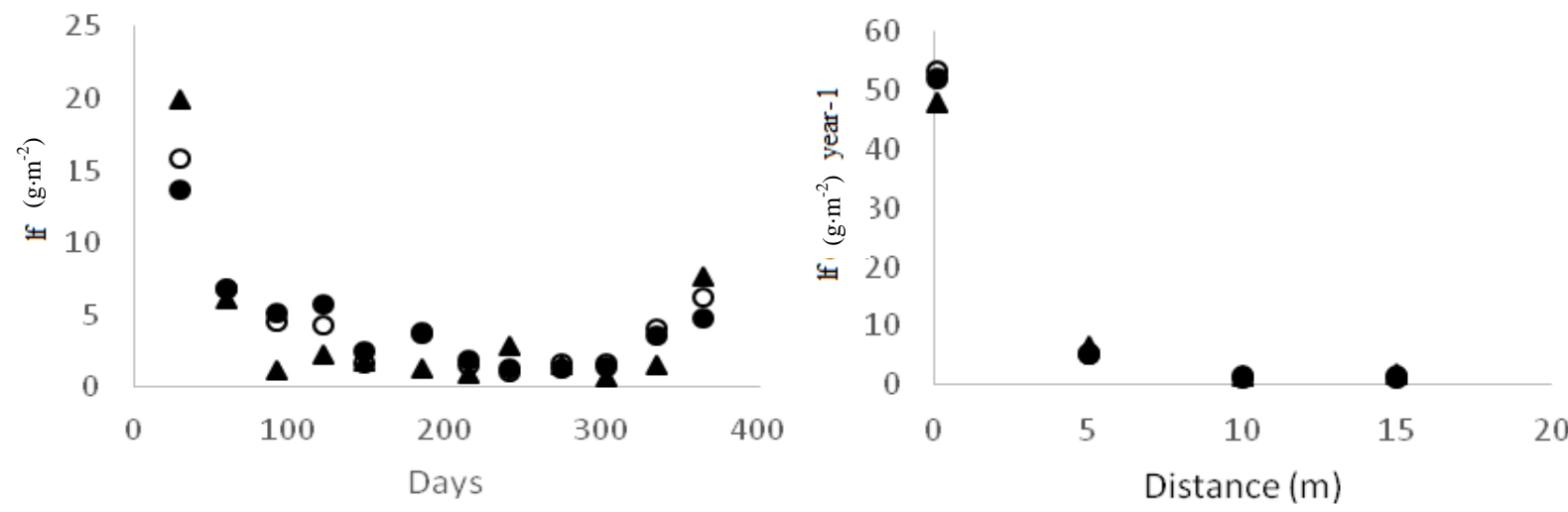

(B3)
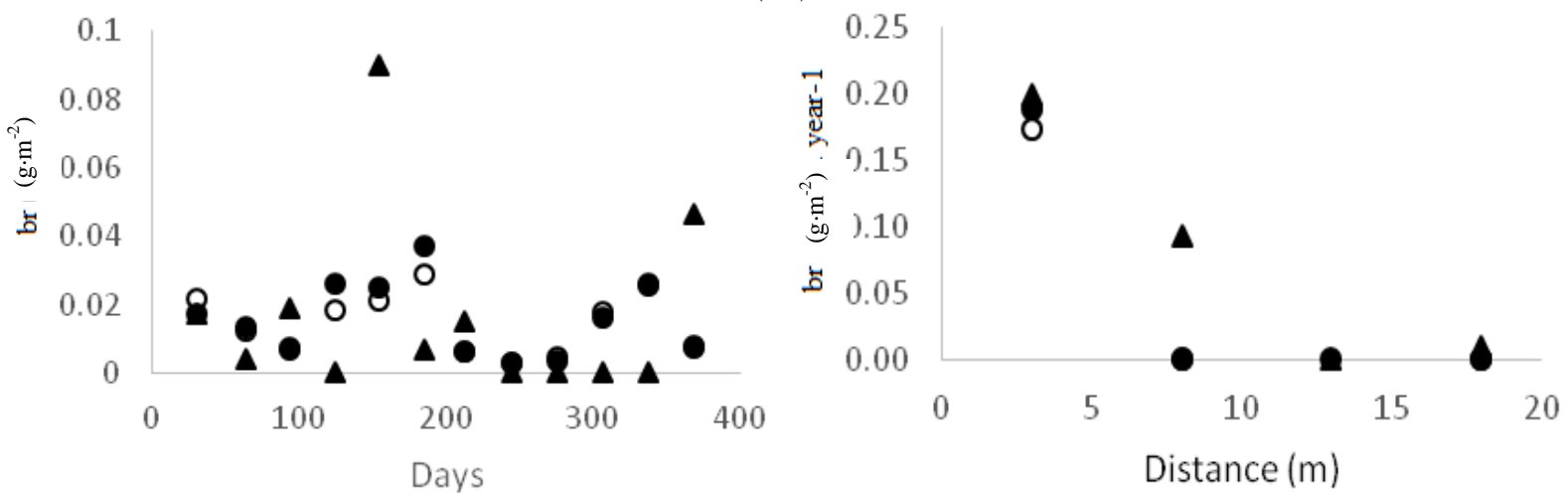

(C1)
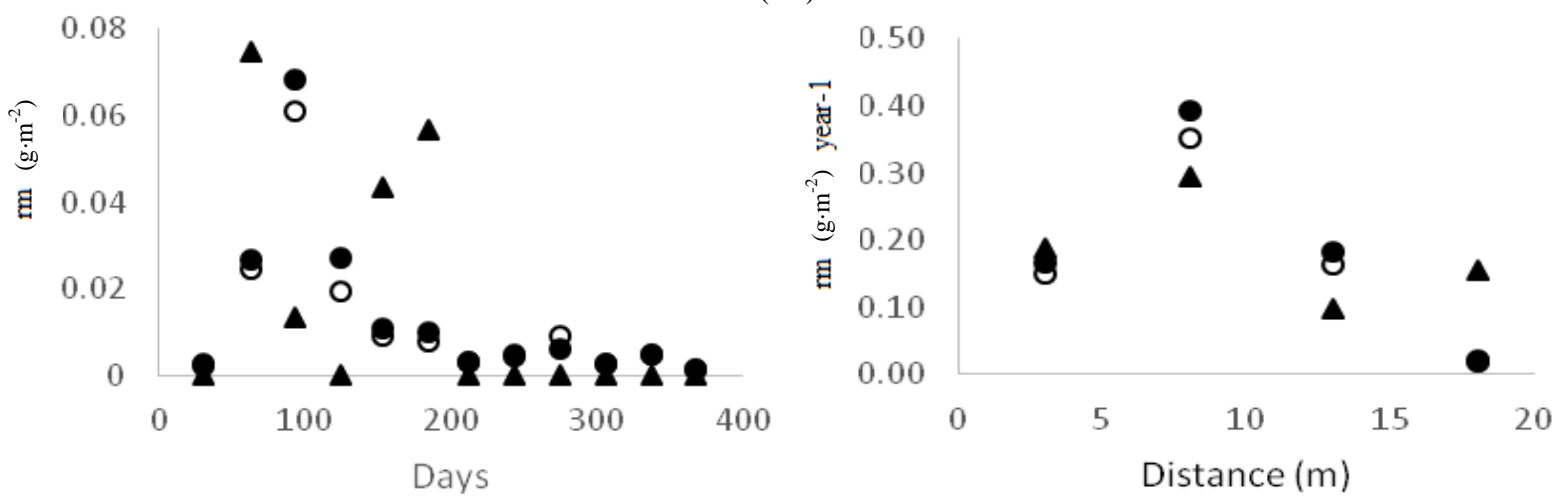

(C2)
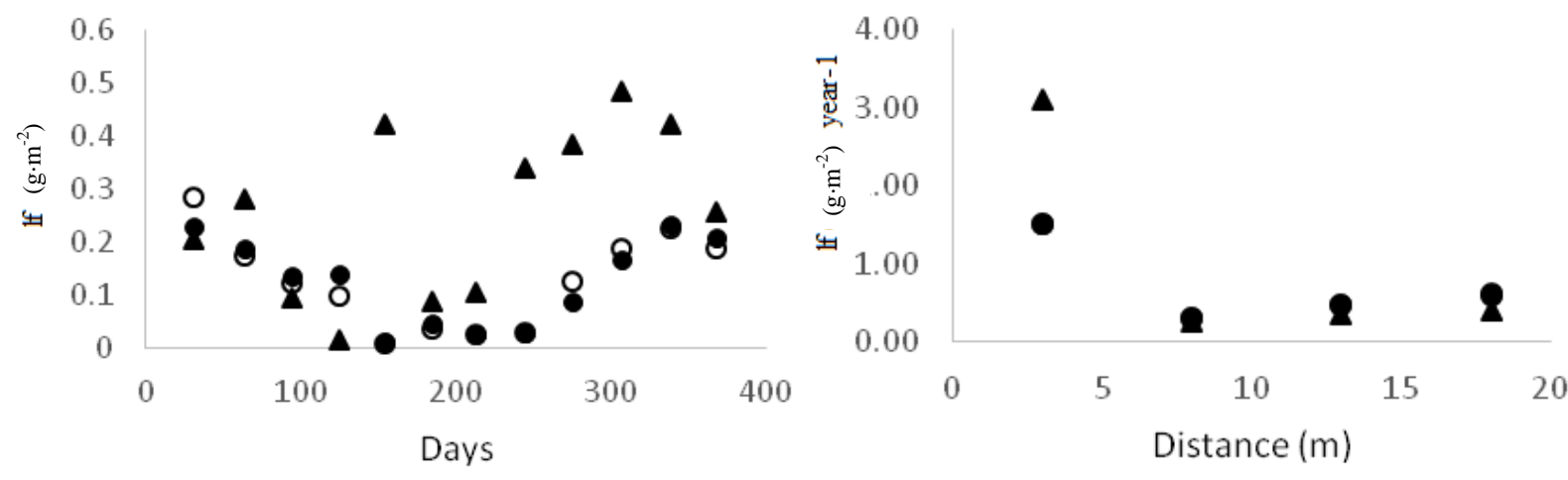

(C3)

Fig. 4 Litterfall observed $(\Delta)$, estimate $(\bullet)$, estimate less wind's model $(\circ)$ on edge by periods (left graphs), and by distances in one year (right graphs), in which br: branch; rm: reproductive material; lf: leaf, to area 51 (A), area 81 (B) and area 61 (C). 
Table 5 Litterfall deposition (branches, reproductive material and leaves) by distance, weighted average wind speed and favorable wind frequencies for $12 \mathrm{~h}$ and $18 \mathrm{~h} \mathrm{UTC}$, and water deficit for the reference periods.

\begin{tabular}{|c|c|c|c|c|}
\hline & Period ref. & $18 / 10 / 11^{*}$ & 27/08-28/10/14 & 28/08-30/10/15 \\
\hline & & $g \cdot m^{-2}$ & & \\
\hline Patch & lf & 190.64 & 280.7 & 164.42 \\
\hline Edge & $\mathrm{br}+\mathrm{rm}+\mathrm{lf}$ & 96.3 & 47.5 & \\
\hline $3 \mathrm{~m}$ & $\mathrm{br}+\mathrm{rm}+\mathrm{lf}$ & & & 0.71 \\
\hline $5 \mathrm{~m}$ & $\mathrm{br}+\mathrm{rm}+\mathrm{lf}$ & 27.1 & 6.62 & \\
\hline $8 \mathrm{~m}$ & $\mathrm{br}+\mathrm{rm}+\mathrm{lf}$ & & & 0.33 \\
\hline $10 \mathrm{~m}$ & $\mathrm{br}+\mathrm{rm}+\mathrm{lf}$ & 16.7 & 3.4 & \\
\hline $13 \mathrm{~m}$ & $\mathrm{br}+\mathrm{rm}+\mathrm{lf}$ & & & 0.28 \\
\hline $15 \mathrm{~m}$ & $\mathrm{br}+\mathrm{rm}+\mathrm{lf}$ & 17.8 & 2.7 & \\
\hline $18 \mathrm{~m}$ & $\mathrm{br}+\mathrm{rm}+\mathrm{lf}$ & & & 0.26 \\
\hline $20 \mathrm{~m}$ & $\mathrm{br}+\mathrm{rm}+\mathrm{lf}$ & 13.7 & - & \\
\hline Weighted average of wind speed $\left(\mathrm{m} \cdot \mathrm{s}^{-1}\right)$ & & 0.57 & 0.62 & 0.52 \\
\hline Frequency of favorable winds & & $\begin{array}{l}59 \\
(\mathrm{~N}, \mathrm{NE}, \mathrm{NW}, \mathrm{SW}, \mathrm{W})\end{array}$ & $\begin{array}{l}47 \\
(\mathrm{~N}, \mathrm{NE}, \mathrm{NW}, \mathrm{W})\end{array}$ & $\begin{array}{l}59 \\
(\mathrm{~N}, \mathrm{NE}, \mathrm{NW}, \mathrm{W})\end{array}$ \\
\hline Water deficit (mm) & & -413.7 & -395.29 & -387.09 \\
\hline
\end{tabular}

*The period is 95 days and it began on 13/07/11.

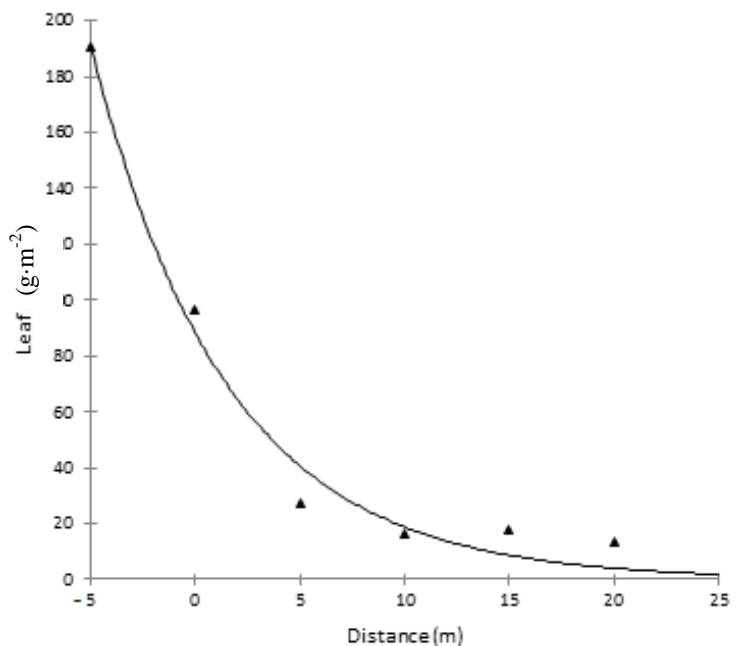

(A)

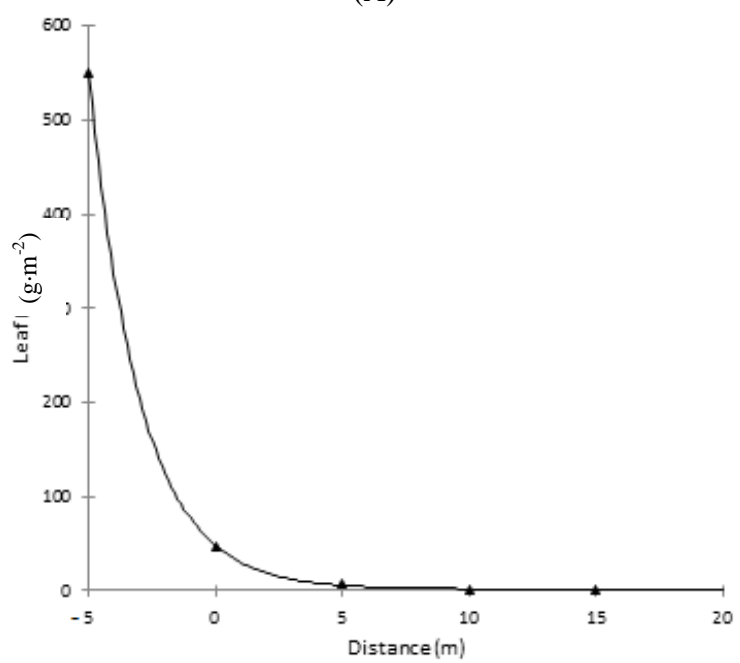

(B)

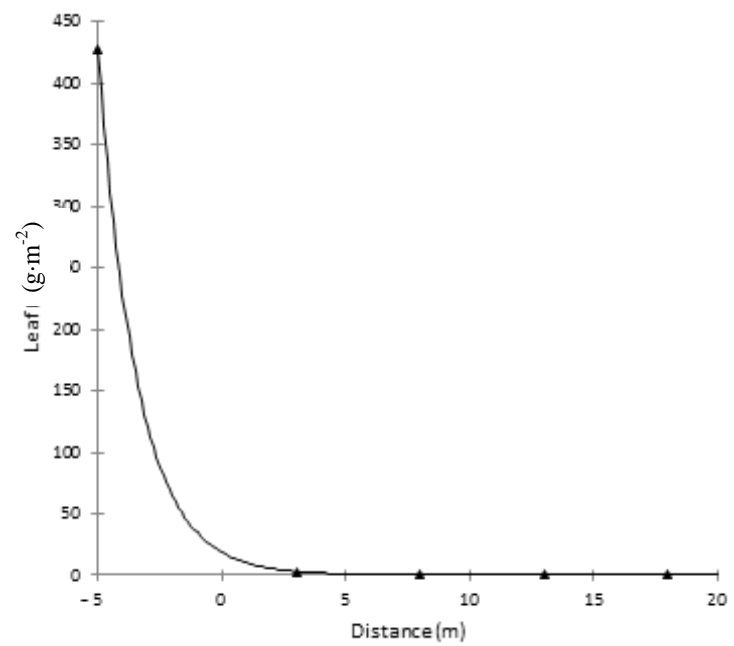

(C)

Fig. 5 Dry weight average of litterfall (d.w.) as function to the distance of the patch for the collection (A): period $15 / 07 / 11$ to $18 / 10 / 11\left(\mathrm{~g} / \mathrm{m}^{2}\right)$, for $(\mathrm{B})$ : the period of $27 / 08 / 14$ to 28/07/15 and (C): period 28/08/15 to $29 / 07 / 16$ (g/m $/$ year).

Then, the drift of nutrients from forests to adjacent areas is function of distance from the edges, and the wind conditions, topographical surfaces and structure of vegetation will influence. At the areas 51, 81 and 61 , the quantity of nutrients deposited by distance in one year can be estimated. This was done to nutrients of the leaves. The leaf analysis of macro and micronutrients from leaves collected within the patch is presented in Table 6, and the amount of nutrients 
deposited in $\mathrm{kg} / \mathrm{ha} / \mathrm{year}$ into the forest, as it moves away from the edge, is given in Table 7.

Maize is reference crop in Brazil, common in family farming and broad-spectrum in agricultural activity. It is used data from export of nutrients at maize harvest, according to their productivity [30] (Table 8), for calculating the percentage of nutrients that the forest can offer in the replacement of these nutrients, disregarding factors affecting the mineralization of organic matter.

Table 6 Quantity of average nutrients of the litter leaves to rain and dry periods. Nitrogen (N) is not analyzed in dry period.

\begin{tabular}{|c|c|c|c|c|c|c|c|c|c|c|c|c|}
\hline & & & & $\mathrm{N}$ & $\mathrm{P}$ & K & $\mathrm{Ca}$ & $\mathrm{Mg}$ & $\mathrm{Zn}$ & $\mathrm{Fe}$ & $\mathrm{Mn}$ & $\mathrm{Cu}$ \\
\hline Season & Area & Plot & Net & \multicolumn{5}{|c|}{--------------dag/kg (\%)--------------- } & \multicolumn{4}{|c|}{--------------mg/kg (ppm)------------- } \\
\hline \multirow[t]{20}{*}{ rain } & 51 & 1 & 1 & 1.48 & 0.08 & 0.81 & 2.82 & 0.36 & 22.7 & 322.3 & 51.6 & 12.8 \\
\hline & & & 2 & 1.81 & 0.09 & 1.08 & 2.81 & 0.46 & 36.0 & 469.6 & 90.0 & 11.1 \\
\hline & & & 3 & 0.96 & 0.07 & 0.60 & 2.31 & 0.31 & 40.3 & 324.8 & 115.4 & 4.9 \\
\hline & & & 4 & 1.73 & 0.08 & 0.81 & 2.30 & 0.30 & 23.9 & 407.2 & 143.9 & 13.5 \\
\hline & & & 5 & 1.65 & 0.08 & 0.67 & 2.56 & 0.31 & 27.9 & 389.5 & 82.1 & 11.9 \\
\hline & & 2 & 1 & 1.34 & 0.09 & 0.90 & & 0.33 & 28.3 & 376.7 & 78.6 & 6.0 \\
\hline & & & 2 & 1.27 & 0.09 & 0.75 & 1.87 & 0.21 & 29.8 & 360.4 & 67.5 & 9.0 \\
\hline & & & 3 & 1.13 & 0.10 & 0.64 & 1.86 & 0.21 & 25.7 & 369.8 & 119.0 & 5.9 \\
\hline & & & 4 & 1.19 & 0.15 & 0.66 & 1.96 & 0.21 & 24.4 & 334.1 & 79.5 & 7.0 \\
\hline & & & 5 & 1.19 & 0.11 & 0.69 & 2.03 & 0.21 & 34.8 & 357.5 & 79.5 & 6.5 \\
\hline & 61 & 3 & 1 & 1.14 & 0.11 & 0.94 & 1.67 & 0.28 & 28.1 & 274.8 & 185.7 & 6.9 \\
\hline & & & 2 & 1.04 & 0.18 & 0.70 & 1.63 & 0.23 & 26.5 & 317.4 & 199.9 & 4.3 \\
\hline & & & 3 & 1.05 & 0.20 & 0.82 & 1.92 & 0.26 & 20.5 & 291.4 & 325.1 & 6.5 \\
\hline & & & 4 & 1.19 & 0.16 & 1.02 & 2.52 & 0.40 & 26.9 & 313.4 & 161.6 & 8.8 \\
\hline & & & 5 & 1.24 & 0.17 & 1.14 & 2.38 & 0.31 & 27.6 & 369.4 & 140.9 & 7.6 \\
\hline & 81 & 1 & 1 & 1.36 & 0.06 & 0.84 & 1.83 & 0.38 & 28.6 & 247.8 & 351.2 & 7.4 \\
\hline & & & 2 & 1.14 & 0.08 & 0.85 & 1.61 & 0.26 & 27.8 & 157.8 & 298.8 & 7.7 \\
\hline & & & 3 & 1.24 & 0.06 & 0.66 & 2.01 & 0.28 & 21.3 & 237.5 & 297.6 & 6.9 \\
\hline & & & 4 & 1.13 & 0.06 & 0.57 & 1.88 & 0.27 & 25.1 & 286.3 & 318.2 & 7.8 \\
\hline & & & 5 & 1.19 & 0.06 & 0.60 & 1.48 & 0.23 & 27.0 & 237.4 & 369.2 & 6.3 \\
\hline \multirow[t]{20}{*}{ dry } & 51 & 1 & 1 & & 0.14 & 0.84 & 2.81 & 0.36 & 27.88 & 377.09 & 106.05 & 16.66 \\
\hline & & & 2 & & 0.16 & 0.86 & 2.69 & 0.39 & 31.26 & 350.86 & 129.69 & 9.84 \\
\hline & & & 3 & & 0.11 & 0.53 & 2.18 & 0.34 & 29.12 & 497.30 & 214.33 & 10.85 \\
\hline & & & 4 & & 0.10 & 0.72 & 2.34 & 0.35 & 25.40 & 668.71 & 337.25 & 14.26 \\
\hline & & & 5 & & 0.13 & 0.72 & 3.11 & 0.37 & 30.34 & 632.95 & 132.10 & 14.86 \\
\hline & & 2 & 1 & & 0.13 & 0.65 & 3.27 & 0.35 & 23.59 & 500.48 & 196.91 & 8.50 \\
\hline & & & 2 & & 0.21 & 0.88 & 2.06 & 0.32 & 47.37 & 804.16 & 103.89 & 22.89 \\
\hline & & & 3 & & 0.18 & 0.69 & 2.18 & 0.33 & 35.37 & 553.53 & 189.49 & 12.59 \\
\hline & & & 4 & & 0.18 & 0.62 & 2.53 & 0.31 & 31.68 & 621.45 & 240.64 & 11.42 \\
\hline & & & 5 & & 0.19 & 0.90 & 2.69 & 0.30 & 37.45 & 765.79 & 146.10 & 14.62 \\
\hline & 61 & 3 & 1 & & 0.14 & 0.71 & 2.34 & 0.35 & 41.42 & 465.73 & 362.76 & 10.36 \\
\hline & & & 2 & & 0.22 & 0.66 & 1.88 & 0.34 & 38.32 & 399.24 & 297.13 & 9.93 \\
\hline & & & 3 & & 0.18 & 0.77 & 2.07 & 0.29 & 25.66 & 538.18 & 300.59 & 12.77 \\
\hline & & & 4 & & 0.15 & 0.60 & 2.18 & 0.33 & 28.44 & 373.50 & 192.84 & 11.39 \\
\hline & & & 5 & & 0.17 & 0.86 & 2.29 & 0.42 & 40.89 & 558.86 & 235.04 & 12.23 \\
\hline & 81 & 1 & 1 & & 0.11 & 0.85 & 2.36 & 0.45 & 25.27 & 442.93 & 298.77 & 10.79 \\
\hline & & & 2 & & 0.09 & 0.76 & 2.21 & 0.43 & 23.15 & 302.70 & 283.47 & 10.01 \\
\hline & & & 3 & & 0.10 & 0.66 & 2.64 & 0.43 & 27.61 & 252.55 & 278.90 & 9.72 \\
\hline & & & 4 & & 0.09 & 0.46 & 2.50 & 0.36 & 26.01 & 299.77 & 260.01 & 11.43 \\
\hline & & & 5 & & 0.14 & 1.04 & 3.48 & 0.65 & 25.63 & 419.43 & 281.05 & 10.35 \\
\hline
\end{tabular}


Table 7 Nutrients quantity (kg/ha/year) deposited by leaves as function of distance of patch.

\begin{tabular}{lllllllllll}
\hline & & & & & & & & \\
\hline Area & Position & $\mathrm{N}$ & $\mathrm{P}$ & $\mathrm{K}$ & $\mathrm{Ca}$ & $\mathrm{Mg}$ & $\mathrm{Zn}$ & $\mathrm{Fe}$ & $\mathrm{Mn}$ & $\mathrm{Cu}$ \\
\hline 51 & Patch & 55.31 & 5.31 & 29.93 & 95.27 & 12.98 & 0.12 & 2.00 & 0.60 & 0.05 \\
\hline & edge & 25.56 & 2.45 & 13.83 & 44.01 & 6.00 & 0.06 & 0.93 & 0.28 & 0.02 \\
& $5 \mathrm{~m}$ & 11.81 & 1.13 & 6.39 & 20.33 & 2.77 & 0.03 & 0.43 & 0.13 & 0.01 \\
& $10 \mathrm{~m}$ & 5.45 & 0.52 & 2.95 & 9.39 & 1.28 & 0.01 & 0.20 & 0.06 & 0.00 \\
& $15 \mathrm{~m}$ & 2.52 & 0.24 & 1.36 & 4.34 & 0.59 & 0.01 & 0.09 & 0.03 & 0.00 \\
& $20 \mathrm{~m}$ & 1.16 & 0.11 & 0.63 & 2.01 & 0.27 & 0.00 & 0.04 & 0.01 & 0.00 \\
\hline 81 & Patch & 66.14 & 5.04 & 40.91 & 130.49 & 22.71 & 0.14 & 1.68 & 1.62 & 0.05 \\
\hline & edge & 5.59 & 0.43 & 3.46 & 11.03 & 1.92 & 0.01 & 0.14 & 0.14 & 0.00 \\
& $5 \mathrm{~m}$ & 0.47 & 0.04 & 0.29 & 0.93 & 0.16 & 0.00 & 0.01 & 0.01 & 0.00 \\
& $10 \mathrm{~m}$ & 0.04 & 0.00 & 0.02 & 0.08 & 0.01 & 0.00 & 0.00 & 0.00 & 0.00 \\
& $15 \mathrm{~m}$ & 0.00 & 0.00 & 0.00 & 0.01 & 0.00 & 0.00 & 0.00 & 0.00 & 0.00 \\
\hline 61 & Patch & 48.30 & 7.10 & 32.12 & 90.29 & 13.96 & 0.14 & 1.82 & 1.09 & 0.04 \\
& $3 \mathrm{~m}$ & 0.32 & 0.05 & 0.21 & 0.59 & 0.09 & 0.00 & 0.01 & 0.01 & 0.00 \\
& $8 \mathrm{~m}$ & 0.01 & 0.00 & 0.01 & 0.03 & 0.00 & 0.00 & 0.00 & 0.00 & 0.00 \\
& $13 \mathrm{~m}$ & 0.00 & 0.00 & 0.00 & 0.00 & 0.00 & 0.00 & 0.00 & 0.00 & 0.00
\end{tabular}

Table 8 Nutrition requirements $(\mathrm{kg} / \mathrm{ha})$ of maize crop for productivity of $3.65 \mathrm{t} / \mathrm{ha}$ [30], and percent of reposition of macro and micronutrients offered by forest patches.

\begin{tabular}{lllllllllll}
\hline Area & & \multicolumn{7}{c}{$\mathrm{kg} / \mathrm{ha}$} \\
& & $\mathrm{N}$ & $\mathrm{P}$ & $\mathrm{K}$ & $\mathrm{Ca}$ & $\mathrm{Mg}$ & $\mathrm{Zn}$ & $\mathrm{Fe}$ & $\mathrm{Mn}$ & $\mathrm{Cu}$ \\
& & 77 & 9 & 83 & 10 & 10 & 0.16 & 0.84 & 0.14 & 0.04 \\
\hline & Dist.(m) & & & \multicolumn{7}{c}{ \% provided by leaves of litterfall } \\
\hline 51 & Patch & 71.84 & 59.00 & 36.06 & 952.68 & 129.80 & 76.87 & 239.80 & 443.88 & 107.27 \\
\hline & edge & 33.19 & 27.26 & 16.66 & 440.14 & 59.97 & 35.51 & 110.79 & 205.08 & 49.56 \\
& $5 \mathrm{~m}$ & 15.33 & 12.59 & 7.70 & 203.35 & 27.70 & 16.41 & 51.19 & 94.75 & 22.90 \\
& $10 \mathrm{~m}$ & 7.08 & 5.82 & 3.56 & 93.95 & 12.80 & 7.58 & 23.65 & 43.77 & 10.58 \\
& $15 \mathrm{~m}$ & 3.27 & 2.69 & 1.64 & 43.41 & 5.91 & 3.50 & 10.93 & 20.22 & 4.89 \\
& $20 \mathrm{~m}$ & 1.51 & 1.24 & 0.76 & 20.05 & 2.73 & 1.62 & 5.05 & 9.34 & 2.26 \\
\hline 81 & Patch & 85.90 & 56.02 & 49.29 & $1,304.94$ & 227.06 & 88.64 & 201.35 & $1,200.02$ & 118.17 \\
\hline & edge & 7.26 & 4.74 & 4.17 & 110.29 & 19.19 & 7.49 & 17.02 & 101.43 & 9.99 \\
& $5 \mathrm{~m}$ & 0.61 & 0.40 & 0.35 & 9.32 & 1.62 & 0.63 & 1.44 & 8.57 & 0.84 \\
& $10 \mathrm{~m}$ & 0.05 & 0.03 & 0.03 & 0.79 & 0.14 & 0.05 & 0.12 & 0.72 & 0.07 \\
& $15 \mathrm{~m}$ & 0.00 & 0.00 & 0.00 & 0.07 & 0.01 & 0.00 & 0.00 & 0.00 & 0.00 \\
\hline & Patch & 62.73 & 78.94 & 38.69 & 902.89 & 139.63 & 85.18 & 217.39 & 805.70 & 101.64 \\
\hline & $3 \mathrm{~m}$ & 0.41 & 0.52 & 0.25 & 5.93 & 0.92 & 0.56 & 1.43 & 5.29 & 0.67 \\
& $8 \mathrm{~m}$ & 0.02 & 0.02 & 0.01 & 0.26 & 0.04 & 0.02 & 0.06 & 0.23 & 0.03
\end{tabular}

The results show that the contribution to the soil fertility maintenance in the surroundings of forest patch can vary a lot. The replacement of Ca by leaves deposition reaches $43 \%$ at a distance of 15 meters in area 51 , but to areas 81 and 61 , the amount of nutrients is already very lower in 3 meters due to lower drift of leaves in these places.

The great variation of the nutrient deposition by the distance between the areas shows that the contribution of vegetable material by means of drift to areas of the forest surroundings has a great influence of the vegetation structure, not only the water balance, 
topographical configuration and winds.

Even if the annual supply of nutrients by air has small magnitude, in long periods of accumulation, the amount can be considered a benefit for agriculture, especially with low input use, when chemical fertilizers are not applied. With a multiplicative annual effect of the deposited material, one can have the dimension of how much the forests contribute to the improvement of the quality of the soil for the surrounding areas.

The nutritional contribution of forest ecosystems for these areas is an ecosystem service [21]. It is likely that the major importance of this kind of supply of nutrients occurs in mountain agriculture, in wavy relief, with forest in the tops and pastures and fields on the slopes. And it has many small crops and grassland in farms vicinity of environmental reserves. In all these environments, this kind of deposition of organic matter can be increased by the mobility of nutrients through runoff and leaching upstream, not measured in this work.

\section{Conclusion}

Neighboring areas of forest ecosystem studied receive contribution of litterfall and their nutrients contained in the organic matter through drift.

The variation of drift of litterfall to adjacent areas is large. It depends of structure of vegetation, direction of wind and topography of area. The estimates with model considering wind factor did not contribute enough to accuracy of results.

It was confirmed that model estimated the leaf drift by distance with good precision.

\section{Acknowledgments}

\section{Thanks} to Project CNPq 487727/2013-4-Agroecological production of the field to city, performance of the Guayi Agroecology Group as CVT (Technological Vocational Center) in Agroecology and Organic Production in Minas Gerais State and Project MP6
06.14.07.006.00.02.008-Agroecological Transition. Authors thank to Vinicius Leal and Iago Ferreira who helped in installation and measurements of data, and to Dra Leila Ferraz, Coordinator of the CNPq Project by support for this research.

\section{References}

[1] Andrade, A. G., Tavares, S. D. L., and Coutinho, H. D. C. 2003. "Contribuição da Serapilheira para Recuperação de Areas Degradadas e para Manutenção da Sustentabilidade de Sistemas Agroecológicos.” Informe Agropecuário 24 (220): 55-63. (in Portuguese)

[2] Menezes, C. E. G., Pereira, M. G., Fernandes Correia, M. E., Cunha dos Anjos, L. H., Ribeiro Paula, R., and de Souza, M. E. 2010. “Aporte e Decomposição da Serapilheira e Produção de Biomassa Radicular em Florestas com Diferentes Estágios Sucessionais em Pinheiral, RJ.” Ciência Florestal 20 (3): 439-52. (in Portuguese)

[3] Ewel, J. J. 1976. "Litter Fall and Leaf Decomposition in a Tropical Forest Succession in Eastern Guatemala.” The Journal of Ecology 64: 293-308.

[4] Nadelhoffer, K. J., and Blair, J. M. 1999. "Measuring Decomposition, Nutrient Turnover, and Stores in Plant Litter.” Standard Soil Methods for Long-Term Ecological Research: 202.

[5] Arato, H. G., Martins, S. V., and Ferrari, S. H. D. S. 2003. "Produção e Decomposição de Serapilheira em um Sistema Agroflorestal Implantado para Recuperação de Area Degradada em Viçosa-MG.” Revista Árvore 27 (5): 715-21. (in Portuguese)

[6] Spain, A. V. 1984. "Litterfall and the Standing Crop of Litter in Three Tropical Australian Rainforests." The Journal of Ecology 72: 947-61. doi: 10.2307/2259543.

[7] Gomes, J. M., Pereira, M. G., Piña-Rodrigues, F., Pereira, G. H., Gondim, F. R., and da Silva, E. M. 2010. "Aporte de Serapilheira e de Nutrientes em Fragmentos Florestais da Mata Atlântica, RJ.” Revista Brasileira de Ciências Agrárias 5 (3): 383-91. (in Portuguese). doi: 10.5039/agraria.v5i3a552.

[8] Munari Vogel, H. L., Schumacher, M. V., Trüby, P., and Vuaden, E. 2007. “Avaliação da Devolução de Serapilheira em uma Floresta Estacional Decidual em Itaara, RS, Brasil.” Ciência Florestal 17 (3): 187-96. (in Portuguese)

[9] Maman, A. P., Silva, C. D., Sguarezi, E. M., and Bleich, M. E. 2007. "Produção e Acúmulo de Serapilheira e Decomposição Foliar em Mata de Galeria e Cerradão no Sudoeste de Mato Grosso.” Revista de Ciências Agro-Ambientais 5 (1): 71-84. (in Portuguese) 
[10] König, F. G., Brun, E. J., Schumacher, M. V., and Longhi, S. J. 2002. "Devolução de Nutrientes via Serapilheira em um Fragmento de Floresta Estacional Decidual no Município de Santa Maria, RS.” Brasil Florestal 74: 45-52. (in Portuguese). doi: 10.1590/S0100-67622002000400005.

[11] da Cunha, G. C., Grendene, L. A., Durlo, M. A., and Bressan, D. A. 1999. "Dinâmica Nutricional em Floresta Estacional Decidual com ênfase aos Minerais Provenientes da Deposição da Serapilheira.” Ciência Florestal 3 (1): 35-64. (in Portuguese)

[12] da Silva Santana, J. A., and Silva Souto, J. 2011. "Produção de Serapilheira na Caatinga da Região Semiárida do Rio Grande do Norte, Brasil.” IDESIA 29 (2): 87-94. (in Portuguese). doi: 10.4067/ S0718-34292011000200011.

[13] Costa, T. C. C., Viana, J. H. M., and Ribeiro, J. L. 2014. "Semideciduous Seasonal Forest Production of Leaves and Deciduousness in Function of the Water Balance, LAI and NDVI.” International Journal of Ecology: 1-15. doi: 10.1155/2014/923027.

[14] Giácomo, R. G., Pereira, M. G., and Machado, D. L. 2012. “Aporte e Decomposição de Serapilheira em Areas de Cerradão e Mata Mesofítica na Estação Ecológica de Pirapitinga-MG.” Ciência Florestal 22 (4): 669-80. (in Portuguese). doi: 10.5902/198050987549.

[15] Silva, C. D., Lobo, F. D. A., Bleich, M. E., and Sanches, L. 2009. "Contribuição de Folhas na Formação da Serapilheira e no Retorno de Nutrientes em Floresta de Transição no Norte de Mato Grosso.” Acta Amazonica 39 (3): 591-600. (in Portuguese)

[16] Silva, C. J. D., Sanches, L., Bleich, M. E., Lobo, F. D. A., and Nogueira, J. D. S. 2007. "Produção de Serrapilheira no Cerrado e Floresta de Transição Amazônia-Cerrado do Centro-Oeste Brasileiro.” Acta Amazônica 37 (4): 543-8. (in Portuguese). doi: 10.1590/S0044-59672007000400009.

[17] Vital, A. R. T., Guerrini, I. A., Franken, W. K., and Fonseca, R. C. B. 2004. "Produção de Serapilheira e Ciclagem de Nutrientes de uma Floresta Estacional Semidecidual em Zona Ripária.” Revista Árvore 28 (6): 793-800. (in Portuguese). doi: 10.1590/S0100-67622004000600004.

[18] Filho Figueiredo, A., Moraes Ferreira, G., Schaaf Budant, L., and de Figueiredo, D. J. 2003. “Avaliação Estacional da Deposição de Serapilheira em uma Floresta Ombrófila Mista Localizada no sul do Estado do Paraná.” Ciência Florestal 13 (1): 11-8. (in Portuguese)
[19] Poggiani, F., and Schumacher, M. V. 2000. "Ciclagem de Nutrientes em Florestas Nativas.” Nutrição e fertilização florestal. Piracicaba: IPEF: 427. (in Portuguese)

[20] Ferreira, C. D. 2011. "Deposição, Acúmulo e Decomposição de Serapilheira em Area de Caatingapreservada [monograph].” Centro de Saúde e Tecnologia Rural, Universidade Federal da Paraíba. Campina Grande. (in Portuguese)

[21] Costa, T. C. C., and Miranda, G. A. 2014. "Nutritional Contribution of Litterfall for a Surrounding Forest Area According to the Distance of a Forest Fragment.” Journal of Environment and Ecology 5 (2): 144-58.

[22] Losey, J. E., and Vaughan, M. 2006. "The Economic Value of Ecological Services Provided by Insects.” Bioscience 56 (4): 311-23.

[23] De Marco, P., and Coelho, F. M. 2004. "Services Performed by the Ecosystem: Forest Remnants Influence Agricultural Cultures' Pollination and Production.” Biodiversity and Conservation 13 (7): 1245-55.

[24] Zhang, W., and Swinton, S. M. 2009. "Incorporating Natural Enemies in an Economic Threshold for Dynamically Optimal Pest Management.” Ecological Modelling $220 \quad$ (9): 1315-24. doi: 10.1016/j.ecolmodel.2009.01.027.

[25] Costanza, R., d'Arge, R., De-Groot, R., Farber, S., Grasso, M., Hannon, B., et al. 1997. "The Value of the World's Ecosystem Services and Natural Capital.” Nature 387 (6630): 253-60.

[26] Duncan, D. H., Dorrough, J., White, M., and Moxham, C. 2008. "Blowing in the Wind? Nutrient Enrichment of Remnant Woodlands in an Agricultural Landscape.” Landscape Ecology $23 \quad$ (1): 107-19. doi10.1007/s10980-007-9160-0.

[27] Allen, R. G., Pereira, L. S., Raes, D., and Smith, M. 1998. "Crop Evapotranspiration-Guidelines for Computing Crop Water Requirements-FAO Irrigation and Drainage Paper 56.” FAO, Rome 300 (9): D05109.

[28] Angelocci, L. R., Sentelhas, P. C., and Pereira, A. R. 2002. "Agrometeorologia: Fundamentos e Aplicações Práticas.” Guairá: Agropecuária. (in Portuguese)

[29] Costa, T. C. C., Silva, A. F., Oliveira, L. M. T. D., and Viana, J. H. M. 2015. "Probabilistic Classification of Tree and Shrub Vegetation on Phytogeographic System.” Journal of Environmental Science and Engineering B 4 (6): 315-30.

[30] Cruz, J. C., Karam, D., Monteiro, M. A. R., and Magalhães, P. C. 2008. A Cultura do Milho. Sete Lagoas, Brazil: Embrapa Milho e Sorgo. (in Portuguese) 